\title{
EFFECTS OF WATER DEFICIT DURING MATURATION ON AMINO ACIDS AND JUJUBE FRUIT EATING QUALITY
}

\author{
Jacinta Collado-González ${ }^{1}$, Zulma N. Cruz ${ }^{2}$, Sonia Medina ${ }^{1}$, Carmen D. Mellisho ${ }^{3}$, Pedro Rodríguez ${ }^{2}$, \\ Alejandro Galindo ${ }^{3}$, Isabel Egea ${ }^{4}$, Félix Romojaro ${ }^{4}$, Federico Ferreres ${ }^{1}$, Arturo Torrecillas ${ }^{3 *}$, \\ Angel Gil-Izquierdo ${ }^{1^{*}}$ \\ ${ }^{1}$ Department of Food Science and Technology, CEBAS-CSIC, P.O. Box 164, Espinardo, \\ 30100, Murcia, Spain \\ ${ }^{2}$ Department of Physiology and Biochemistry, Instituto Nacional de Ciencias Agricolas (INCA), \\ Ctra. De Tapaste, km 3.5, San José de Las Lajas, Mayabeque, Cuba \\ ${ }^{3}$ Department of Irrigation, CEBAS-CSIC, P.O. Box 164, Espinardo, E-30100 Murcia, Spain \\ ${ }^{4}$ Department of Biology of the Stress and Plant Pathology, CEBAS-CSIC, P.O. Box 164, Espinardo, \\ E-30100 Murcia, Spain \\ atorrecillas@cebas.csic.es, angelgil@cebas.csic.es
}

Jujube yield and fruit characteristics can be clearly modified by water deficit imposed during fruit maturation. One essential (cystine (Cys-cys)) and seven non-essential (4-hydroxyproline (p-Hyp), $\alpha$ aminoadipic acid (AADA), ornithine (Orn), $\beta$-aminoisobutyric acid (BAIB), $\alpha$-amino-n-butyric acid (AABA), cystathionine (Cysta), and homocystine (Hcys-cys)) amino acids were identified for the first time. Fruits from plants exposed to moderate water deficit during the maturation stage (T1) initiated the ripening phase earlier than control (T0) fruits and had an improved eating quality. Fruits subjected to severe water deficit (T2) showed changes in their physical characteristics and reached a more advanced degree of ripening than T0 and T1 fruits, with not only most of the fruit chemical characteristics that determine taste being improved but also the nutritional value. The decrease in the asparagine (Asn) content of the fruit as a result of severe water deficit is a positive aspect, which prevents acrylamide formation during heat-processing of the fruit.

Keywords: ethylene emission; fruit quality; plant water relations; fruit respiration; amino acids

\section{ВЛИЈАНИЕ НА НЕДОСТИГОТ НА ВОДА ЗА ВРЕМЕ НА СОЗРЕВАЊЕ ВРЗ АМИНОКИСЕЛИНИТЕ И ХРАНЛИВИОТ КВАЛИТЕТ НА ZIZYPHUS JUJUВA}

Приносот и карактеристиките на Zizyphus jujuba очигледно можат да се модифицираат со наметнат недостиг на вода при созревањето. За прв пат се идентификувани една есенцијална (Cyscуs) и седум неесенцијални аминокиселини: 4-хидроксипролин (р-Нур), $\alpha$-аминоадипинска киселина (AADA), орнитин (orn), ß-аминоизобутерна киселина (BAIB), $\alpha$-амино-n-бутерна киселина (AABA), цистатионин (Cysta) и хомоцистин (Hcys-cys). Овошките изложени на умерен недостиг на вода за време на созревањето (Т1) побрзо започнувале со фазата на созревање во однос на овошките од контролната група (Т0) и имале подобар прехранбен квалитет. Овошките изложени на голем недостиг на вода (Т2) покажале промени во физичките карактеристики и достигнувале понапреден степен на созревање од овошките од Т0 и Т1, и тоа не само со подобрени хемиски карактеристики кои го подобруваат вкусот, но и со подобрена нутрициска вредност. Намалувањето на содржината на аспарагин (Asp) во овошките како резултат на голем недостиг на вода има позитивна страна затоа што го спречува образувањето на акриламид за време на топлинската обработка на овошјето. 
Клучни зборови: емисија на етилен; квалитет на овошје; однос на вода и растенија; респирација кај растенија; аминокиселини

\section{INTRODUCTION}

Jujube or Chinese jujube tree (Zizyphus jujuba Mill.) is a native fruit tree of China, where it has been cultivated for more than 5000 years, and yields about 450,000 tons annually in that country alone [1]. Although species of the Zizyphus genus are considered as minor crops, they are an integral part of the culture and way of life of millions of Asian and African people and are considered as crops with substantial growth potential by the International Centre for Underutilized Crops in Southampton, U.K. [2].

Z. jujuba is admired for its wide adaptation, easy management, early bearing, and the nutritional value of its fruit, which is eaten fresh, dried, or processed into confectionary. It is a nutritionally valuable fruit for the variety of essential nutrients it contains such as carbohydrates, crude fibre, crude protein, flavonoids, and several essential minerals and vitamins [3-7]. Moreover, jujube fruits have been shown to possess biological activities associated with the antiproliferation of cancer cells [8], the alleviation of brain nerve disorder [9], regulation of immune function [10], antimicrobial and antiviral properties [11], and the reduction of blood triglyceride levels [12]. It has analeptic, palliative, and antibechic uses [7, 13]. Nevertheless, Choi et al. $[4,6]$ recently identifiedhigh levels of free asparagine (Asn), which is the major precursor of acrylamide, a potentially toxic compound formed during the heat-processing of plant foods $[14,15]$.

From the agronomic point of view, Z. jujuba is a very interesting crop because it is able to withstand severe drought during the growing season. Cruz et al.[16] showed that the jujube tree is able to maintain leaf turgor and productivity under severe water deprivation thanks to two simultaneous and complementary mechanisms: stomatal regulation and active osmotic adjustment. Despite the increasing water shortage in the areas considered most suitable for jujube tree cultivation, hardly any reports exist on the effect of irrigation and its relationship with the jujube fruit yield and quality. An exception is the work of Cui et al. [17], who showed that regulated deficit irrigation improves fruit quality and water use efficiency. It is well known that the free amino acids present in some fruits contribute to their taste and to defense mechanisms against water deficit. Clarifying the changes in amino acid contents is therefore an im- portant step in elucidating the response of jujube fruits to water deficit.

For these reasons, the aim of the present paper was to ascertain whether water deficit during the fruit maturation period is a useful tool for the management of some important quality attributes in jujube fruits. For this, fully irrigated trees were compared with deficit-irrigated trees and trees submitted to a period of non-irrigation during fruit maturation.

\section{EXPERIMENTAL}

The experiment was carried out in 2011 at a farm near the town of Albatera (Alicante, Spain) $\left(38^{\circ} 12^{\prime} \mathrm{N}, 0^{\circ} 51^{\prime} \mathrm{W}\right)$. The plant material consisted of 7-year-old jujube trees (Zizyphus jujuba Mill. cv. Grande de Albatera), planted at $2 \mathrm{~m} \times 6 \mathrm{~m}$. The soil of the orchard is a Torrifluvent with a sandy loam texture, very low electrical conductivity (109 $\mu \mathrm{S} / \mathrm{cm}, 1: 10 w: v)$, high lime content (57\%), very low organic matter content $(0.3 \%)$, and low exchangeable potassium $(40 \mathrm{mg} / \mathrm{kg})$ and available phosphorus $(20 \mathrm{mg} / \mathrm{kg}$ ). The irrigation water had an electrical conductivity of between 1.7 and $2.2 \mathrm{dS} / \mathrm{m}^{2}$ and a $\mathrm{Cl}^{-}$ concentration ranging from 36 to $48 \mathrm{mg} / 1$.

The climate of the area is strictly Mediterranean, with mild winters, low annual rainfall, and hot, dry summers. During the experimental period, the average daily maximum and minimum air temperatures were 32 and $22{ }^{\circ} \mathrm{C}$, respectively, while the mean daily air vapour pressure deficit $\left(\mathrm{VPD}_{\mathrm{m}}\right)$ [18] ranged from 1.25 to $3.25 \mathrm{kPa}$ and the reference crop evapotranspiration (ETo) [18] was 189 $\mathrm{mm}$. The total rainfall was negligible $(1.8 \mathrm{~mm}$ on day of the year, DOY, 221).

Three irrigation treatments were considered, in which irrigation was carried out daily and during the night using a drip irrigation system with one lateral pipe per tree row. Control plants (treatment T0) were irrigated to ensure non-limiting soil water conditions (112\% ETo), T1 plants were irrigated according to the criteria used by the farmer (64\% ETo), and T2 plants were irrigated as in T0 but irrigation was withheld for 36 days (from DOY 202 to 238). The total water amounts applied during the measurement period were 213 and $122 \mathrm{~mm}$ for treatments $\mathrm{T} 0$ and $\mathrm{T} 1$, respectively.

\subsection{Chemicals}

The AQC reagent was purchased from Chemos GmbH (Regenstauf, Germany). The Bis-Tris 
reagent and all amino acid standards (histidine (His), 1-methyl-histidine (Met-His), 4-hydroxyproline (p-Hyp), asparagine (Asn), phosphoethanolamine (PEA), arginine (Arg), glutamine (Gln), serine (Ser), glycine (Gly), ethanolamine (EA), aspartic acid (Asp), citrulline (Cit), glutamic acid (Glu), threonine (Thr), alanine (Ala), $\gamma$-Amino-nbutyric acid (GABA), $\alpha$-Aminoadipic acid (AADA), proline (Pro), Ornithine (Orn), $\beta$-Aminoisobutyric acid (BAIB), $\alpha$-Amino-n-butyric acid (AABA), lysine (Lys), Cystine (Cys-cys), cystathionine (Cysta), tyrosine (Tyr), valine (Val), Methionine (Met), homocystine (Hcys-cys), leucine (Leu), isoleucine (Ile), tryptophan (Trp), and phenylalanine (Phe)) were obtained from Sigma Aldrich (Madrid, Spain). Acetonitrile and methanol (both of LC-MS grade), sulfuric acid, nitric acid, perchloric acid, formic acid, ammonium acetate, ascorbic acid, and sodium hydroxide were obtained from Panreac Química S.A. (Barcelona, Spain), and metaphosphoric acid was from Merck (Darmstadt, Germany). Boric acid was bought from Probus (Badalona, Spain), while arabinose, glucose, sucrose, malic acid, citric acid, oxalic acid, and calcium disodium EDTA were purchased from Sigma (Steinheim, Germany). The Milli-Q water used was produced by an Elix ${ }^{\circledR} 3$ Millipore water purification system (Molsheim, France).

\subsection{Plant water status}

The predawn leaf water potential $\left(\Psi_{\mathrm{pd}}\right)$ was measured in mature leaves located on the south facing side, from the middle third of the tree (two leaves per tree and four trees per treatment), using a pressure chamber (model 3005, Soil Moisture Equipment Co., Santa Barbara, CA, USA). The midday (12 h solar time) stem water potential $\left(\Psi_{\text {stem }}\right)$ was measured in a similar number and type of leaves as $\Psi_{\mathrm{pd}}$ : leaves were enclosed in a small, black plastic bag covered with aluminum foil for at least $2 \mathrm{~h}$ before the measurements in the pressure chamber [19 ].

Midday gas exchange in attached leaves, leaf conductance $\left(\mathrm{g}_{\mathrm{Imd}}\right)$, and net photosynthesis $\left(\mathrm{P}_{\mathrm{nmd}}\right)$, were measured with a field-portable, closed gasexchange photosynthesis system (LI-6400, LICOR Inc., Lincoln, NE, USA), in a similar type of leaf as used for the $\Psi_{1}$ measurements. Two measurements were taken on four trees per treatment.

\subsection{Fruit weight, firmness, and color}

Jujube fruits were harvested in their commercial ripening state (the S7 stage of growth, according to Choi et al. [4]) and immediately transported to the laboratory, on 27 August (DOY 239).
The fruits were divided into the edible portion (peel and pulp) and pit (shell and seed), and the average weight, moisture content, firmness, peel and flesh color, total soluble solids, ethylene emission, and respiratory rate were immediately measured in each fresh edible portion sample. Aliquots of all samples were stored at $-20{ }^{\circ} \mathrm{C}$ and freezedried before other analyses.

Average fruit weight was estimated by weighing 25 fruits per replicate. For the moisture content, samples were oven-dried at $105^{\circ} \mathrm{C}$ to constant weight (AOAC, 2000). The flesh firmness was determined as the load needed to break the flesh after removal of the peel in the equatorial zone, according to Egea et al. [20], using a Penefel-type penetrometer (Copa-Technology, Tarascon, France) equipped with a rod $8 \mathrm{~mm}$ in diameter.

The external and internal color were measured by reflectance with a Minolta CR 2000 colorimeter (Osaka, Japan) and the results were expressed in the CIELAB $L^{*}, a^{*}, b^{*}$ system. The mean values of the lightness $\left(L^{*}\right)$, red-greenness $\left(a^{*}\right)$, and blue-yellowness $\left(b^{*}\right)$, parameters for each fruit were calculated. The objective color was calculated as chromaticity or chroma $\left(C^{*}=\left(a^{* 2}+\right.\right.$ $\left.\left.b^{*^{2}}\right)^{1 / 2}\right)$ and hue angle $\left(H^{o}=\arctan \left(b^{*} / a^{*}\right)\right)[21]$.

\subsection{Fruit ethylene emission and respiratory rate}

Ethylene and $\mathrm{CO}_{2}$ production were determined by placing 16 fruits in a hermetically sealed container, of known volume and equipped with a silicone septum. After $2 \mathrm{~h}, 1$ mlof the internal atmosphere of the container was extracted with a syringe for the determination of ethylene. The ethylene was quantified in a Hewlett-Packard HP5890 (Bristol, United Kingdom), equipped with a flame ionization detector and a stainless-steel column ( $3 \mathrm{~m} \times 3.2 \mathrm{~mm}$ diameter) packed with $80 / 100$ mesh activated alumina. The quantification was carried out following calibration, point-by-point, with an external standard [22]. The $\mathrm{CO}_{2}$ quantification was performed directly in the head space of the container, $2 \mathrm{~h}$ after closure, using a bench-top headspace gas analyzer (PBI Dansensor, CheckMate 9900).

\subsection{Fruit total soluble solids, vitamin $C$, sugar, organic acids, and bioelements}

Total soluble solids (TSS) were determined by measuring the refractive index of the juice extracted from the fruit, with a digital refractometer (Atago, Tokyo, Japan). Titratable acidity (TA) was determined by potentiometric titration with $0.1 \mathrm{~N}$ $\mathrm{NaOH}$ at $\mathrm{pH} 8.1$ [23]. The ripening index was estimated as the ratio between TSS and TA. 
Vitamin C was determined according to Egea et al. [23]. The lyophilized powder of the edible portion $(0.5 \mathrm{~g})$ was diluted with $10 \mathrm{ml}$ of cold $50 \mathrm{ml} / \mathrm{lmetaphosphoric} \mathrm{acid,} \mathrm{making} \mathrm{up} \mathrm{the}$ homogenized mixture to $50 \mathrm{ml}$ with the same solvent. The final solution was kept on ice in darkness for $30 \mathrm{~min}$ and then centrifuged at $20000 \mathrm{~g}$ for 25 min. Then, the supernatant was passed through a C18 Plus Sep-Pack cartridge and a $0.2-\mu \mathrm{m}$ filter. Quantification was carried out with a highperformance liquid chromatograph (Shimadzu LC10Atvp, Kyoto, Japan), using a thermostatted ion exchange column (ION-300) at $30^{\circ} \mathrm{C}$ with isocratic elution. The absorbance at $254 \mathrm{~nm}$ was recorded with a UV-visible detector. A standard curve in the concentration range $10-100 \mathrm{mg} / \mathrm{kg}$ ascorbic acid was used.

To determine the sugar and organic acid contents, lyophilized powder of the fruit edible portion $(0.5 \mathrm{~g})$ was diluted with Milli-Q water (50 $\mathrm{ml})$ and then centrifuged $(1200 \mathrm{~g})$ at $4{ }^{\circ} \mathrm{C}$ for 30 minutes. After centrifugation, the supernatant was filteredthrough a Durapore $0.45 \mu \mathrm{m}$ HV filter (Millipore Corporation, USA) and then passed through a C18 Plus Sep-Pack cartridge (Waters Corporation, Massachusetts, USA). Quantifications were carried out by a Shimadzu LC-10Atvp HPLC (Kyoto, Japan), using a thermostated ion-exchange column (ION-300, Teknochroma) at $30^{\circ} \mathrm{C}$, with isocratic elution of the mobile phase $(2.5 \mathrm{mM}$ $\mathrm{H}_{2} \mathrm{SO}_{4}$ ). Two detectors were connected in tandem: a Shimadzu Refractive Index Detector, to detect the sugars, and a Shimadzu UV-Vis Detector for the spectrophotometric detection of the organic acids. The detection wavelength was $210 \mathrm{~nm}$ for oxalic acid and $230 \mathrm{~nm}$ for citric and malic acids. The sugar and organic acid quantifications were performed by means of calibration curves for each compound prepared with solutions made from standards of each organic acid and sugar [24].

Dried peel and flesh samples from the fruit moisture content determination were finely crushed in an agate mortar prior to determination of the mineral concentrations. The peel and flesh $\mathrm{N}$ concentrations were measured using a Thermo-Finnigan 1112 EA elemental analyzer (Thermo-Finnigan, Milan, Italy). The peel and flesh powders were subjected to nitro-perchloric acid attack $(5: 3, v / v)$ in a microwave oven (CEM Mars Xpress, NC, USA), reaching $200{ }^{\circ} \mathrm{C}$ in $20 \mathrm{~min}$ and holding this temperature for $2 \mathrm{~h}$. The $\mathrm{P}, \mathrm{K}, \mathrm{Ca}, \mathrm{Mg}, \mathrm{S}, \mathrm{Fe}, \mathrm{Mn}$, $\mathrm{Zn}, \mathrm{Cu}$, and $\mathrm{B}$ concentrations of the arils were quantified by inductively coupled plasma emission optical spectrometry (Iris Intrepid II, Thermo Electron Corporation, Franklin, USA).

\subsection{Amino acids}

Individual amino acids (authentic standards) were prepared by dissolving each amine in BisTris ( $\mathrm{pH}$ 6.5). Calibration standards were generated by diluting the stock solutions to $1,0.5,0.25,0.12$, 0.06 , and $0.03 \mathrm{mM}$. In the case of amino thiols, calibration standards were produced by diluting the stock solutions to $2,1,0.5,0.25,0.12$, and 0.06 $\mu \mathrm{M}$ in Milli-Q water.

Free amino acids were determined by following a method described previously [25]. Briefly, 20 $\mathrm{mg}$ of the fine powdered edible portion or pit of the jujube fruits were homogenized with $500 \mu 1$ of extraction buffer $(\mathrm{MeOH} /$ water, 1:1, v/v) using an ultra turrax (IKA, T10, Germany), for 30 seconds on ice. The samples were then incubated on dry ice for 5 minutes. The homogenates were sonicated in an ultrasound bath for 1 minute followed by centrifugation (Eppendorf centrifuge 5804 R, Hamburg, Germany) for 10 minutes at $17900 \mathrm{~g}$, at $4{ }^{\circ} \mathrm{C}$. The supernatants were transferred to limited volume vials and the precipitates were re-extracted with $500 \mu l$ of extraction buffer, homogenized, incubated on ice, and centrifuged again. All supernatants were combined. The extracts were immediately derivatized.

The derivatization of amino acids and amino thiols was accomplished by following the Waters AccQ Tag ${ }^{\mathrm{TM}}$ Ultra UHPLC amino analysis procedures, as described by Nagumo et al. [26] and Salazar et al. [25]. Briefly, $350 \mu \mathrm{l}$ of borate derivatization buffer ( $0.2 \mathrm{M}$ sodium borate, $\mathrm{pH} 8.8$, with 5 $\mathrm{mM}$ calcium disodium EDTA), $50 \mu \mathrm{l}$ of amino acid standard or jujube extract, and $100 \mu \mathrm{l}$ of reconstituted AQC (10 mM AQC dry powder in acetonitrile) were placed in a 2-ml propylene vial [27, 28]. This solution was vortexed for several seconds, allowed to stand for 1 minute at room temperature, and then heated in a heating block for 10 minutes at $55^{\circ} \mathrm{C}$. After removing the vial from the heating block, the sample was injected into a UHPLC-MS/MS.

Amino acids and thiols were analyzed by reverse phase UHPLC as reported by Nagumo et al. [26] and Salazar et al. [25], with slight modifications. Briefly, chromatographic separation was carried out on an AccQ Tag Ultra BEH column $(2.1 \times 100 \mathrm{~mm}, 1.7 \mu \mathrm{m})$ (Waters Corp., Ireland). Two types of eluent were used for gradient separation. Mobile phase A consisted of $50 \mathrm{ml}$ of an aqueous solution (acetonitrile, formic acid, and 5 $\mathrm{mM}$ ammonium acetate in water) $(10: 6: 84, v / v / v)$ diluted with $950 \mathrm{ml}$ of Milli-Q water. Mobile phase $\mathrm{B}$ was a mixture of acetonitrile and formic 
acid $(99.9: 0.1, v / v)$. The injection volume was 20 $\mu \mathrm{l}$ and the elution was performed at a flow rate of $0.5 \mathrm{ml} / \mathrm{min}^{-1}$. The gradient profile was: $99.9 \% \mathrm{~A}$ at $0-0.5 \mathrm{~min}, 90.9 \% \mathrm{~A}$ at $5.7 \mathrm{~min}, 78.8 \% \mathrm{~A}$ at 7.7 $\min , 40.4 \% \mathrm{~A}$ at $8-10 \mathrm{~min}, 10 \% \mathrm{~A}$ at $10.01-12.00$ min, and $99.9 \% \mathrm{~A}$ at $12.01-14.00 \mathrm{~min}$. These compounds were identified using a UHPLC system coupled to a 6460 tandem mass spectrometer (Agilent Technologies, Waldbronn, Germany). Data acquisition and processing were performed using MassHunter software version B.04.00, from Agilent Technologies. The MS analysis was applied in the multiple reaction monitoring (MRM) mode, which was performed using the positive ionization mode. The MS parameters fragmentor (ion optics; capillary exit voltage) and collision energy were optimized for each analyte (Table 6). The allocation of these parameters, along with preferential MRM transition of the corresponding analytes, generated the most abundant product ions. The MRM transition used for each derivatized amino acid/thiol corresponded, in most cases, to the AMQ moiety $\left(171^{+}\right)$- which results from the collision-induced cleavage at the ureide bond of the AMQ adduct of each amino acid/thiol $[25,29]$. The working conditions for the MS parameters of the electrospray source were as follows: gas flow, $9 \mathrm{l} / \mathrm{min}$; nebulizer, $40 \mathrm{psi}$; capillary voltage, $4000 \mathrm{~V}$; nozzle voltage, $1000 \mathrm{~V}$; gas temperature, $325{ }^{\circ} \mathrm{C}$; sheath gas tem- perature, $390{ }^{\circ} \mathrm{C}$; and jetstream gas flow, $11 \mathrm{l} / \mathrm{min}$. The acquisition time was $12 \mathrm{~min}$ for each sample.

\subsection{Statistical design and analysis}

The experiment had a completely randomized design with four replications, each consisting of three adjacent tree rows; each row had 11 trees. Physiological measurements were taken on the inner tree of the central row of each replicate, these trees being healthy, uniform, and very similar in appearance, while the other trees served as border trees. The data were processed using SPSS software version 19 for Windows [30]. One-way analysis of variance was carried out and mean values were compared by Tukey's multiple range test. All means were compared at the 0.05 level of significance. Values for each replicate were averaged before the mean and the standard deviation of each treatment were calculated.

\section{RESULTS AND DISCUSSION}

\subsection{Plant water status}

Significant differences between the irrigation treatments were noted in the $\Psi_{\text {pd }}$ and $\Psi_{\text {stem }}$ values from DOY 209 to 238 (Figures 1B and 1 D).

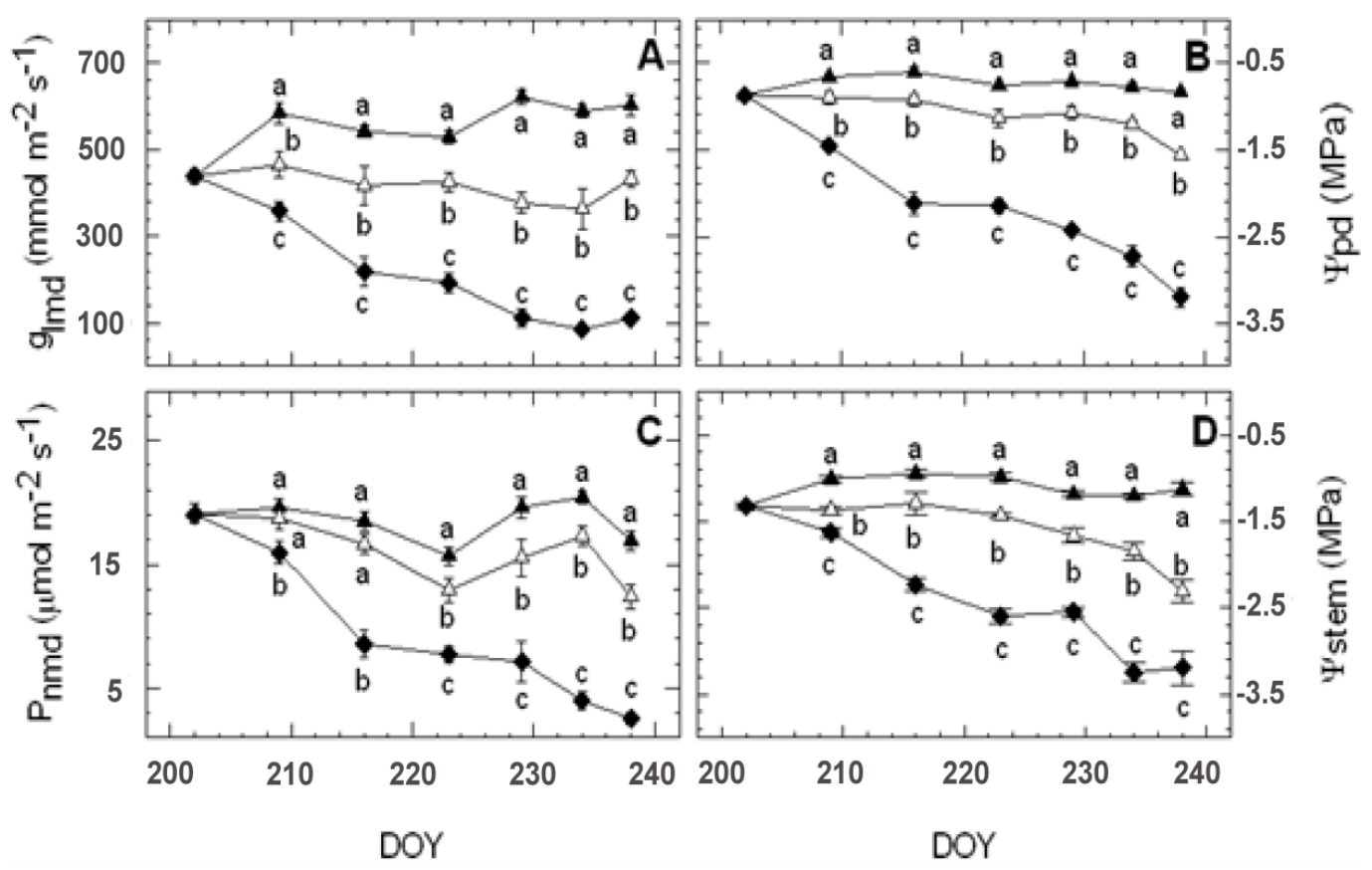

Fig. 1. Midday leaf conductance $\left(\mathrm{g}_{\mathrm{Imd}}, \mathrm{A}\right)$, predawn leaf water potential $\left(\Psi_{\mathrm{pd}}, \mathrm{B}\right)$, midday net photosynthesis $\left(\mathrm{P}_{\mathrm{nmd}}, \mathrm{C}\right)$, and midday stem water potential $\left(\Psi_{\text {stem }}, \mathrm{D}\right)$ values (mean $\pm \mathrm{SE}$, not shown when smaller than symbols, $n=4)$, for jujube plants in treatments T0, T1, and T2 during the experimental period. Different letters on data points at each date indicate significant differences according to Tukey's test $(\mathrm{P} \leq 0.05)$. 
The $\Psi_{\text {pd }}$ and $\Psi_{\text {stem }}$ values in T1 plants were lower than in T0 plants and higher than in T2 plants. In addition, the $\Psi_{\mathrm{pd}}$ values in T0 and T1 plants and $\Psi_{\text {stem }}$ values in T0 plants remained constant during the experimental period, whereas the $\Psi_{\mathrm{pd}}$ and $\Psi_{\text {stem }}$ values in T2 plants and $\Psi_{\text {stem }}$ values in $\mathrm{T} 1$ plants showed a tendency to gradually decrease, reaching minimum values on DOY 238.

The midday leaf conductance $\left(\mathrm{g}_{\mathrm{Imd}}\right)$ and net photosynthesis $\left(\mathrm{P}_{\mathrm{nmd}}\right)$ values during the measurement period were high and nearly constant in T0 plants (Figures 1A and 1C). Moreover, the $\mathrm{g}_{\mathrm{Im}}$ values of $\mathrm{T} 1$ plants were also nearly constant, and intermediate between the $\mathrm{T} 0$ and $\mathrm{T} 2$ values (Figure 1A). However, the $\mathrm{g}_{\mathrm{Imd}}$ and $\mathrm{P}_{\mathrm{nm}}$ values in $\mathrm{T} 2$ plants gradually decreased during the stress period, reaching minimum values on DOY 238.

Considering that $\Psi_{\mathrm{pd}}$ values depend on soil moisture levels $[31,32]$, the high and constant $\Psi_{\mathrm{pd}}$ values in T0 plants during the experiment indicate that these plants were not exposed to limiting soil water conditions (Figure 1B). Moreover, the existence of significant differences in the $\Psi_{\mathrm{pd}}, \Psi_{\text {stem }}$, $\mathrm{g}_{\mathrm{Imd}}$, and $\mathrm{P}_{\mathrm{nmd}}$ values among treatments point to a water deficit situation in $\mathrm{T} 1$ and $\mathrm{T} 2$ plants (Figure 1). The water deficit in the T1 plants can be considered as moderate because the $\Psi_{\mathrm{pd}}$ and $\Psi_{\text {stem }}$ values in $\mathrm{T} 1$ plants reached minimum values of -1.56 and $-2.28 \mathrm{MPa}$, respectively, while the $\mathrm{g}_{\mathrm{Imd}}$ and $\mathrm{P}_{\mathrm{nmd}}$ values were relatively high and constant, although lower than those in T0. At the end of the measurement period, the T2 plants showed very low $\Psi_{\mathrm{pd}}$ and $\Psi_{\text {stem }}$ values (-3.20 and $-3.14 \mathrm{MPa}$, respectively) (Figures 1B and D) and a considerable degree of stomatal regulation compared with the $\mathrm{T} 1$ plants (Figures $1 \mathrm{~A}$ and $\mathrm{C}$ ), indicating that treatment $\mathrm{T} 2$ induced a more severe water deficit.

\subsection{Fruit weight, firmness and color}

The total marketable jujube yield of the T1 plants was higher than that of the T2 plants and lower than for the $\mathrm{T} 0$ plants (Table 1). The fruit from $\mathrm{T} 0$ and $\mathrm{T} 1$ trees showed similar average weight, moisture content, and firmness. In contrast, T2 fruits showed the lowest average weight and moisture content, but the greatest firmness (Table 1).

Changes in fruit peel and flesh color were only observed in T2 fruits (Table 2). In this sense, the peel and flesh $H^{\circ}$ values of T2 fruits were lower than those of T0 and T1 fruits, and the peel and flesh $a^{*}$ and flesh $b^{*}$ values of T2 fruits were higher than in the other treatments. The flesh $L^{*}$ values of $\mathrm{T} 2$ fruits were decreased with respect to those of $\mathrm{T} 0$ and $\mathrm{T} 1$ fruits.
Fruit yield in the three irrigation treatments $\left(833-2500 \mathrm{~g} \mathrm{~m}^{-2}\right.$ or $10-30 \mathrm{~kg} \mathrm{tree}^{-1}$ ) (Table 1) can be considered as adequate according to the yields mentioned by Gao et al. [33] for different cultivars $\left(130-1800 \mathrm{~g} \mathrm{~m}^{-2}\right)$ and those obtained by Cui et al. [17], who considered the effect of different deficit irrigation levels during different growth stages $(14-24 \mathrm{~kg} /$ tree $)$. However, in contrast with our results, these authors indicated that low, moderate, or severe water deficit during the fruit maturation stage (stage III, early August - early September) had no significant effect on fruit yield and size but reduced the fruit water content. Unfortunately, Cui et al. [17] did not evaluate quantitatively the water status of the plants under severe water deficits and so our results cannot be compared with theirs.

\section{Table 1}

Effect of irrigation treatments on jujube yield $\left(\mathrm{kg}^{\mathrm{tree}} \mathrm{e}^{-1}\right)$, average fruit weight $(F W, \mathrm{~g})$, fruit moisture content $(M C, \%)$, and fruit firmness $(F F, N)$

\begin{tabular}{ccccc}
\hline \hline Treatment & Yield & FW & MC & FF \\
\hline T0 & $31.81 \mathrm{a}$ & $30.23 \mathrm{a}$ & $83.47 \mathrm{a}$ & $64.00 \mathrm{~b}$ \\
$\mathrm{~T} 1$ & $21.36 \mathrm{~b}$ & $27.98 \mathrm{a}$ & $79.66 \mathrm{a}$ & $66.67 \mathrm{~b}$ \\
$\mathrm{~T} 2$ & $9.59 \mathrm{c}$ & $14.40 \mathrm{~b}$ & $64.95 \mathrm{~b}$ & $82.33 \mathrm{a}$ \\
\hline \hline
\end{tabular}

Means within a column that do not have a common letter are significantly different according to Tukey's test $(P \leq$ $0.05)$.

The fruit size reduction observed in $\mathrm{T} 2$ fruits (Table 1) could be related to the results obtained recently (data not shown) in a very similar experiment by Cruz, who found that, in contrast with the axiom that expansive cell growth requires cell turgor, jujube fruit size in plants under severe water stress was reduced even though fruit turgor was maintained. This may have been due to enhancement of the cell elasticity mechanism (elastic adjustment), to maintain fruit turgor by reducing fruit cell size. The fact that jujube fruits under severe water deficit (T2) showed greater firmness could be related to the decreased moisture content in these fruits (Table 1), leading to a gummy and corklike flesh structure. In this sense, Wu et al. [34] showed that Z. Jujube fruit firmness increased at the end of the ripening period (fruit surface 100\% red ) as a consequence of the lower fruit water content. This phenomenon has been observed in other fruits, such as plums, which became stiff, leading to an increase in the firmness values expressed as the load needed to break the flesh [35]. 
Changes in fruit peel and flesh color were evident in the T2 irrigation treatment (Table 2). The severe water stress induced changes in the fruit peel $a^{*}$ and $H^{o}$ values (from green towards a more intense red color). These changes were less pronounced in the fruit flesh, which remained greener than the peel and showed a lower degree of luminosity while its colour was yellower than that of the T0 and $\mathrm{T} 1$ fruit flesh (Table 2).

Table 2

Effect of irrigation treatments on jujube fruit peel and flesh lightness $\left(L^{*}\right)$, red-greenness $\left(a^{*}\right)$, blue-yellowness $\left(b^{*}\right)$, chroma $\left(C^{*}\right)$, and hue angle $\left(H^{0}\right)$ values

\begin{tabular}{cccrccccccc}
\hline \hline & \multicolumn{2}{c}{$L^{*}$} & \multicolumn{2}{c}{$a^{*}$} & \multicolumn{2}{c}{$b^{*}$} & \multicolumn{2}{c}{$C^{*}$} & \multicolumn{2}{c}{$H^{0}$} \\
\cline { 2 - 11 } Treatment & Peel & Flesh & Peel & \multicolumn{1}{c}{ Flesh } & Peel & Flesh & Peel & Flesh & Peel & Flesh \\
\hline T0 & $78.02 \mathrm{a}$ & $88.43 \mathrm{a}$ & $-12.09 \mathrm{~b}$ & $-12.21 \mathrm{~b}$ & $45.04 \mathrm{a}$ & $24.42 \mathrm{~b}$ & $46.64 \mathrm{a}$ & $27.30 \mathrm{a}$ & $105.04 \mathrm{a}$ & $116.57 \mathrm{a}$ \\
T1 & $79.26 \mathrm{a}$ & $88.17 \mathrm{a}$ & $-11.18 \mathrm{~b}$ & $-12.13 \mathrm{~b}$ & $44.66 \mathrm{a}$ & $25.17 \mathrm{~b}$ & $46.05 \mathrm{a}$ & $27.94 \mathrm{a}$ & $104.06 \mathrm{a}$ & $115.73 \mathrm{a}$ \\
T2 & $67.55 \mathrm{a}$ & $79.27 \mathrm{~b}$ & $3.04 \mathrm{a}$ & $-9.91 \mathrm{a}$ & $40.37 \mathrm{a}$ & $27.16 \mathrm{a}$ & $41.08 \mathrm{a}$ & $28.91 \mathrm{a}$ & $84.27 \mathrm{~b}$ & $110.02 \mathrm{~b}$ \\
\hline \hline
\end{tabular}

Means within a column that do not have a common letter are significantly different according to Tukey's test $(P \leq 0.05)$.

\subsection{Fruit ethylene emission, respiratory rate, and total soluble solids}

Fruit ethylene emission was increased in $\mathrm{T} 1$ and $\mathrm{T} 2$ fruits with respect to the T0 fruits (Table $3)$. However, the fruit respiratory rate was highest in $\mathrm{T} 1$ fruits and lowest in $\mathrm{T} 2$ fruits, while T0 fruits showed intermediate values (Table 3). Flesh TSS showed their minimum values in T0 fruits and were highest in T2 fruits, T1 fruits showing intermediate values. The TA values were unaffected by the irrigation treatment, but the TSS/TA ratio in T2 fruits was significantly higher than in $\mathrm{T} 0$ and $\mathrm{T} 1$ fruits (Table 3).

T a b le 3

Effect of irrigation treatments on jujube fruit ethylene emission $\left(C_{2} H_{4}, n L \mathrm{hg} F W\right)$, respiratory rate $\left(\mathrm{RR}, \mathrm{CO}_{2} \mathrm{mg} / \mathrm{h} \mathrm{kg} \mathrm{FW}\right)$, total soluble solids (TSS, ${ }^{\circ}$ Brix), titratable acidity (TA, \% malic acid), and ripening index (TSS/TA)

\begin{tabular}{cccccc}
\hline \hline Treatment & $\mathrm{C}_{2} \mathrm{H}_{4}$ & RR & TSS & TA & TSS/TA \\
\hline T0 & $0.027 \mathrm{~b}$ & $59.35 \mathrm{~b}$ & $15.47 \mathrm{c}$ & $0.25 \mathrm{a}$ & $61.31 \mathrm{~b}$ \\
$\mathrm{~T} 1$ & $0.143 \mathrm{a}$ & $66.37 \mathrm{a}$ & $20.20 \mathrm{~b}$ & $0.32 \mathrm{a}$ & $62.56 \mathrm{~b}$ \\
$\mathrm{~T} 2$ & $0.118 \mathrm{a}$ & $56.17 \mathrm{c}$ & $26.83 \mathrm{a}$ & $0.36 \mathrm{a}$ & $77.53 \mathrm{a}$ \\
\hline \hline
\end{tabular}

Means within a column that do not have a common letter are significantly different according to Tukey's test $(P \leq 0.05)$.

Kader et al. [36] concluded that Z. jujuba fruits followed a non-climateric pattern. In contrast, Abbas and Saggar [37] and Abbas and Fandi [38], in Z. mauritiana fruits, and Al-Niami et al. [39], in Z. spina-christi fruits, showed a climacteric behaviour. Moreover, coinciding with these observations in closely related species, Zhang et al. [40] and Wang et al. [41] recently indicated that $Z$. jujuba fruits are climacteric. In this sense, the increase in ethylene emission and respiratory rate in T1 fruits reflect the fact that under moderate water deficit the fruits entered the ripening phase earlier than control (T0) fruits [39]. In addition, the increase in ethylene emission in $\mathrm{T} 2$ fruits - compared with $\mathrm{T} 0$ fruits - and the decrease in fruit res- piratory rate in $\mathrm{T} 2$ fruits - compared with both $\mathrm{T} 0$ and $\mathrm{T} 1$ fruits - reflect the finding that under severe water deficit (T2) the fruits reach a higher degree of ripening [38].

\subsection{Fruit vitamin C, sugar, organic acids and bioelements}

The T2 fruit showed higher concentrations of vitamin $\mathrm{C}$, sucrose, glucose, arabinose, malic acid, and oxalic acid and a lower citric acid content than T0 fruits (Table 4). These organic compounds showed similar values in $\mathrm{T} 0$ and $\mathrm{T} 1$ fruits, except sucrose and arabinose, which increased significantly in T1 fruits (Table 4). 
T a ble 4

Effect of irrigation treatments on jujube fruit vitamin $C(\mathrm{mg} / 100 \mathrm{~g} \mathrm{FW})$, sucrose $(\mathrm{mg} / 100 \mathrm{~g} \mathrm{FW})$, glucose ( $m g / 100 \mathrm{~g} \mathrm{FW})$, arabinose (mg/100 $\mathrm{g} \mathrm{FW}$ ), malic acid (MA, $\mathrm{mg} / 100 \mathrm{~g} \mathrm{FW})$, citric acid $(C A, m g / 100 \mathrm{~g} F W)$, and oxalic acid (OA, $m g / 100 \mathrm{~g} F W)$

\begin{tabular}{clcccccc}
\hline \hline Treatment & Vitamin C & Sucrose & Glucose & Arabinose & MA & CA & OA \\
\hline T0 & $375.33 \mathrm{~b}$ & $8954.03 \mathrm{~b}$ & $4029.59 \mathrm{~b}$ & $3567.76 \mathrm{c}$ & $520.34 \mathrm{~b}$ & $272.71 \mathrm{a}$ & $34.46 \mathrm{~b}$ \\
T1 & $380.65 \mathrm{~b}$ & $23808.80 \mathrm{a}$ & $3833.23 \mathrm{~b}$ & $4368.44 \mathrm{~b}$ & $530.88 \mathrm{~b}$ & $284.76 \mathrm{a}$ & $26.66 \mathrm{~b}$ \\
$\mathrm{~T} 2$ & $590.04 \mathrm{a}$ & $18564.92 \mathrm{a}$ & $8815.84 \mathrm{a}$ & $9217.86 \mathrm{a}$ & $715.37 \mathrm{a}$ & $191.92 \mathrm{~b}$ & $57.12 \mathrm{a}$ \\
\hline \hline
\end{tabular}

Means within a column that do not have a common letter are significantly different according to Tukey's test $(P \leq 0.05)$.

The most abundant bioelements in the edible portion of jujube fruits were $\mathrm{K}, \mathrm{N}, \mathrm{Ca}, \mathrm{P}$, and $\mathrm{Mg}$, followed, in descending order, by $\mathrm{S}, \mathrm{Na}, \mathrm{B}, \mathrm{Zn}$, $\mathrm{Mn}, \mathrm{Fe}$, and $\mathrm{Cu}$ (Table 5). Some changes in the nutrient content of the fruit edible portion were observed among the three irrigation treatments. In this respect, the mineral content of $\mathrm{T} 1$ fruits was very similar to that observed in $\mathrm{T} 0$ fruits, except that the $\mathrm{K}, \mathrm{P}$, and $\mathrm{Cu}$ contents were lower (Table 5). In contrast, the $\mathrm{K}, \mathrm{N}, \mathrm{P}, \mathrm{Mg}, \mathrm{S}, \mathrm{B}, \mathrm{Mn}, \mathrm{Fe}$, and $\mathrm{Cu}$ contents in the edible portion of $\mathrm{T} 2$ fruits were lower than in $\mathrm{T} 0$ fruits, whereas the $\mathrm{Ca}, \mathrm{Na}$ and $\mathrm{Zn}$ levels were similar to those in $\mathrm{T} 0$ and $\mathrm{T} 1$ fruits (Table 5).

Under our experimental conditions, the jujube $\mathrm{T} 0$ fruits showed a vitamin $\mathrm{C}$ content (Table 4) similarto those found by Cui et al. [17] in fruits from cv. Lizao and by Gao et al. [42] in fruits from
10 promising jujube selections (Lingbaozao, Puaisanhao, Fengmiguan, Junzao, Zaowangzao, Jinchangyihao, Taigumizao, Qingjianmuzao, and Jiaxianmuzao) and higher than those found by Li et $a l$. [7] in fruits from five different $Z$. jujuba cultivars (Jinsixiaozao, Yazao, Jianzao, Junzao, and Sanbianhong). These values confirm that the jujube fruit is a rich source of ascorbic acid compared with other fruit species: according to the Food and Nutrition Board of the National Research Council [43], one 20-g portion of jujube fruit (a medium size fruit) could provide almost the entire daily vitamin $\mathrm{C}$ requirement of an adult. The increase in vitamin $\mathrm{C}$ content in fruits under severe water deficit (T2) (Table 4) is in line with the results of Cui et al. [17] and could have resulted from a concentration effect due to the decrease in fruit moisture content (Table 1).

Table 5

Effect of irrigation treatments on some mineral nutrient contents $(\mathrm{mg} / \mathrm{l} 00 \mathrm{~g} \mathrm{DW})$ in the edible portion (peel and flesh) of jujube fruit

\begin{tabular}{ccccccccccccc}
\hline \hline Treatment & $\mathrm{K}$ & $\mathrm{N}$ & $\mathrm{Ca}$ & $\mathrm{P}$ & $\mathrm{Mg}$ & $\mathrm{S}$ & $\mathrm{Na}$ & $\mathrm{B}$ & $\mathrm{Zn}$ & $\mathrm{Mn}$ & $\mathrm{Fe}$ & $\mathrm{Cu}$ \\
\hline $\mathrm{T} 0$ & $1052 \mathrm{a}$ & $839 \mathrm{a}$ & $66 \mathrm{a}$ & $54 \mathrm{a}$ & $49 \mathrm{a}$ & $24 \mathrm{a}$ & $6 \mathrm{a}$ & $1.61 \mathrm{a}$ & $0.70 \mathrm{a}$ & $0.68 \mathrm{a}$ & $0.51 \mathrm{a}$ & $0.23 \mathrm{a}$ \\
$\mathrm{T} 1$ & $864 \mathrm{~b}$ & $749 \mathrm{a}$ & $52 \mathrm{a}$ & $45 \mathrm{~b}$ & $41 \mathrm{ab}$ & $21 \mathrm{a}$ & $5 \mathrm{a}$ & $1.69 \mathrm{a}$ & $0.61 \mathrm{a}$ & $0.63 \mathrm{ab}$ & $0.50 \mathrm{ab}$ & $0.16 \mathrm{~b}$ \\
$\mathrm{~T} 2$ & $630 \mathrm{c}$ & $587 \mathrm{~b}$ & $57 \mathrm{a}$ & $39 \mathrm{~b}$ & $35 \mathrm{~b}$ & $13 \mathrm{~b}$ & $4 \mathrm{a}$ & $1.10 \mathrm{~b}$ & $0.57 \mathrm{a}$ & $0.51 \mathrm{~b}$ & $0.32 \mathrm{~b}$ & $0.06 \mathrm{c}$ \\
\hline \hline
\end{tabular}

Means within a column that do not have a common letter are significantly different according to Tukey's test $(P \leq 0.05)$.

In contrast with the findings of other authors [7],the sugars detected in the Grande de Albatera cultivar fruits were mainly sucrose, glucose, and arabinose, along with traces of fructose. The presence of arabinose, one of the major neutral sugars in insoluble and soluble dietary fiber, suggests another favourable nutritional aspect of these fruits. High amounts of arabinose could be due to neutral arabinogalactan type polysaccharides or also the pectic type, which are linked to galacturonic acid residues [44]. The fact that the arabinose content of $\mathrm{T} 2$ fruits was higher than that of $\mathrm{T} 0$ and
T1 fruits agrees with the effect of water deficit on the cell wall of the date palm fruit observed by Gribaa et al. [45]. These authors showed that the arabinose content was significantly higher in the pectin-enriched extracts from fruits under nonirrigated conditions and suggested that this could be involved in maintaining the hydration of the cell and cell wall flexibility under water deficit.

Moderate water deficit (T1) increased the sucrose and arabinose contents, as reflected in the higher TSS levels (Tables 3 and 4), indicating that moderate water deficit during fruit maturation im- 
proves jujube fruit eating quality because the fruits taste sweeter. Severe water deficit (T2) improved not only the fruit taste but also the nutritional value, because these fruits showed increases in sucrose, glucose, arabinose, vitamin $\mathrm{C}$, malic acid, and oxalic acid, but also a decrease in citric acid (Table 4).

The overall level of bioelements in the edible portion of jujube fruits (Table 5) differed slightly with respect to those found in five different cultivars by $\mathrm{Li}$ et al. [7]. For example, K was the predominant bioelement in both cases but we observed levels higher than those in cultivar Yazao, the richest source of $\mathrm{K}$ among the Chinese jujube cultivars studied by Li et al. [7]. Also, the $\mathrm{Zn}$ contents were above those reported by Favier et al. [46] and Li et al. [7] , although the Ca content was similar to that reported by Favier et al. [46] and that found in cultivar Jinsixiaozao by Li et al. [7]. $\mathrm{The} \mathrm{Mg}$ and $\mathrm{Na}$ contents were within the range found by Favier et al. [46] and Li et al. [7], although $\mathrm{P}$ and the micronutrients $\mathrm{Cu}, \mathrm{Fe}$, and $\mathrm{Mn}$ showed values clearly lower than those reported by Li et al. [7]. These differences could be ascribed to the cultivar's efficiency for nutrient uptake, the edaphoclimatic conditions, or cultural practices [47]. Severe water deficit (T2) induced decreases in the $\mathrm{K}, \mathrm{N}, \mathrm{P}, \mathrm{Mg}, \mathrm{S}, \mathrm{B}, \mathrm{Mn}, \mathrm{Fe}$, and $\mathrm{Cu}$ contents in the edible portion of the fruits, compared with T0, while moderate water deficit (T1) induced no changes in the fruit content of most of the bioelements, except $\mathrm{K}, \mathrm{P}$, and $\mathrm{Cu}$, which were lower than in T0 fruits (Table 5). These findings agree with the idea that drought restricts not only water acquisition but also nutrient uptake [20, 21, 48].

\subsection{Amino acids}

Thirty-two free amino acids were found in the pitand the edible portion of jujube fruits, 11 of them essential and 21 non-essential (Tables 6-8). In this sense, two essential (Cys-cys and Met) and two non-essential (Cysta and Hcys-cys) amino acids fall within the definition of amino thiols since they have a sulfhydryl group.

The edible portion of $\mathrm{T} 2$ fruits showed significantly lower contents of total free and total essential free amino acids than that of T0 fruits (Table 7). While the edible portion of $\mathrm{T} 1$ fruits had a total free amino acid content similar to that of $\mathrm{T} 0$ fruits, the total essential free amino acid content was similar to that of $\mathrm{T} 2$ fruits and lower than that of T0 fruits (Table 7). Differences were observed among the responses of the free amino acids to $\mathrm{T} 1$ and T2 deficit irrigation. For example, while the levels of free amino acids in the edible portion of
T2 fruits had an overall tendency to decrease with respect to those in T0 fruits, Pro, Trp, and Cysta increased while His, Cys-cys, Met-his, BAIB, and Hcys-cys did not change. In the edible portion of $\mathrm{T} 1$ fruits, the levels of most of the free amino acids were similar to those in T0 fruits, except for 13 amino acids, 11 of which (Tyr, Leu + Ile, Phe, PEA, Gln, Asp, Cit, AADA, Orn, BAIB, and AABA) showed lower values and two (Cys-cys and Cysta) higher values (Table 7).

The effects of T1 and T2 on the concentrations of pit free amino acids were very different from those observed in the edible portion of the fruit (Tables 7 and 8). The total free amino acids and total essential free amino acids contents were similar for all three irrigation treatments. However, the responses of the amino acids to the $\mathrm{T} 1$ and $\mathrm{T} 2$ treatments differed greatly. For example, T2 decreased the levels of 12 amino acids (Thr, Lys, pHyp, Asn, Gln, Ser, Gly, Glu, Ala, GABA, Orn, and Hcys-cys), compared with $\mathrm{T} 0$, and increased the levels of 11 (Cys-cys, Met, Trp, Phe, PEA, Arg, EA, AADA, Pro, AABA, and Cysta), while eight amino acids (His, Tyr, Val, Leu + Ile, Methis, Asp, Cit, and BAIB) showed similar levels in the T2 and T0 pits. As regards T1, 20 amino acids (His, Thr, Lys, Tyr, Leu + Ile, Trp, Phe, Met-his, p-Hyp, Asn, Arg, EA, Gly, Asp, Cit, Ala, AADA, BAIB, AABA, and Hcys-cys) showed levels similar to those of T0 pits, whereas five (Cys-cys, Met, PEA, Pro, and Cysta) showed higher concentrations and six (Val, Gln, Ser, Glu, GABA, and Orn) lower concentrations, compared with T0 pits (Table 8).

It is important to emphasize that the free amino acids identified in the edible portion (peel and flesh) and pit (shell and seed) of jujube fruits (Table 6) showed some differences with respect to those identified in three Korean cultivars (Boeumdeachu, Mechu, and Sanzoin) by Choi et al. $[4,6]$ These authors identified cysteine (Cys) and hydroxylysine (Hyl), which were not found in the fruits of the Grande de Albatera cultivar. However, to the best of our knowledge, this is the first time that the following have been identified in $Z$. jujuba fruits: one essential amino acid (Cys-cys) and seven non-essential amino acids (p-Hyp, AADA, Orn, BAIB, AABA, Cysta, and HCys-Cys) (Table 6). The presence of four amino thiols (Cys-cys, Met, Cysta and Hcys-cys) in jujube fruits can also be considered a valuable aspect, because biothiols are the most important antioxidants that protect cells from oxidative damage [49]. Also, Zagorchev et al. [50] indicated that the data available so far suggest that thiols play a central role in the abiotic stress tolerance of plants. 
The levels of total amino acids in the edible portion of $\mathrm{T} 0$ fruit (Table 7) were similar to those found in the fruit pulp of the Boeum-deachu and Mechu cultivars [6]. The total essential amino acid content in the T0 fruit edible portion (Table 7) was also similar to that found in the fruit pulp of culti- var Sanzo in [6]. However, the sums of the total and total essential amino acids in T0 pits (Table 7) were clearly lower than those found in the seeds of three Korean cultivars by Choi et al. [6], probably due to a dilution effect of the shell portion.

\section{Table 6}

MS parameters of the free amino acids identified in jujube fruits under UHPLC-QqQ-MS/MS conditions by the use of AQC derivatization [25, 26]

\begin{tabular}{|c|c|c|c|c|c|c|}
\hline ID & Amino acid & $\begin{array}{l}\text { Parent ion } \\
\qquad(\mathrm{m} / \mathrm{z})\end{array}$ & $\begin{array}{l}\text { Daughter ion } \\
\qquad(\mathrm{m} / \mathrm{z})\end{array}$ & Fragmentor & $\begin{array}{l}\text { Collision } \\
\text { energy }\end{array}$ & $\begin{array}{c}t_{\mathrm{R}} \\
(\mathrm{min})\end{array}$ \\
\hline 1 & His & 326.2 & 171 & 100 & 0 & 3.53 \\
\hline 2 & Met-his & 340.2 & 171 & 100 & 10 & 3.61 \\
\hline 3 & p-Нyp & 302.1 & 171 & 120 & 0 & 3.64 \\
\hline 4 & Asn & 303.1 & 171 & 100 & 0 & 3.99 \\
\hline 5 & PEA & 312.4 & 171 & 80 & 0 & 4.00 \\
\hline 6 & $\operatorname{Arg}$ & 345.2 & 171 & 100 & 0 & 4.16 \\
\hline 7 & Gln & 317.2 & 171 & 110 & 0 & 4.43 \\
\hline 8 & Ser & 276.1 & 171 & 80 & 0 & 4.47 \\
\hline 9 & EA & 232.1 & 171 & 100 & 0 & 4.48 \\
\hline 10 & Gly & 246.1 & 171 & 90 & 0 & 4.72 \\
\hline 11 & Asp & 304.1 & 171 & 140 & 0 & 5.13 \\
\hline 12 & Cit & 340.2 & 171 & 100 & 10 & 5.20 \\
\hline 13 & Glu & 318.1 & 171 & 110 & 0 & 5.39 \\
\hline 14 & Thr & 290.1 & 171 & 120 & 0 & 5.66 \\
\hline 15 & Ala & 260.2 & 171 & 100 & 0 & 6.12 \\
\hline 16 & GABA & 274.1 & 171 & 90 & 0 & 6.18 \\
\hline 17 & AADA & 332.3 & 171 & 110 & 0 & 6.64 \\
\hline 18 & Pro & 286.2 & 171 & 90 & 0 & 6.69 \\
\hline 19 & Orn & 473.2 & 171 & 110 & 5 & 7.09 \\
\hline 20 & BAIB & 274.1 & 171 & 80 & 0 & 7.12 \\
\hline 21 & $\mathrm{AABA}$ & 274.1 & 171 & 110 & 0 & 7.26 \\
\hline 22 & Lys & 487.2 & 171 & 90 & 5 & 7.34 \\
\hline 23 & Cys-cys & 581.6 & 171 & 90 & 0 & 7.38 \\
\hline 24 & Cysta & 563.3 & 171 & 100 & 0 & 7.54 \\
\hline 25 & Tyr & 352.2 & 171 & 90 & 0 & 7.88 \\
\hline 26 & Val & 288.2 & 171 & 110 & 0 & 7.99 \\
\hline 27 & Met & 320.2 & 171 & 90 & 0 & 8.00 \\
\hline 28 & Hcys-cys & 609.4 & 171 & 130 & 0 & 8.32 \\
\hline 29 & Leu + Ileu & 302.2 & 171 & 100 & 0 & 8.65 \\
\hline 30 & Trp & 375.2 & 171 & 120 & 0 & 8.68 \\
\hline 31 & Phe & 336.2 & 171 & 100 & 0 & 8.69 \\
\hline
\end{tabular}

Abbreviations used: Histidine (His), 1-methyl-histidine (Met-His), 4-hydroxyproline (p-Hyp), asparagine (Asn), phosphoethanolamine (PEA), arginine (Arg), glutamine (Gln), serine (Ser), ethanolamine (EA), glycine (Gly), aspartic acid (Asp), citrulline (Cit), glutamic acid (Glu), threonine (Thr), alanine (Ala), $\gamma$-amino- $n$-butyric acid (GABA), $\alpha$-aminoadipic acid (AADA), proline (Pro), ornithine (Orn), $\beta$-aminoisobutyric acid (BAIB), $\alpha$-amino-n-butyric acid (AABA), lysine (Lys), cystine (Cys-Cys), cysthationine (Cysta), tyrosine (Tyr), valine (Val), methionine (Met), homocystine (HCys-Cys), leucine (Leu), alloisoleucine (Ileu), tryptophan (Trp), phenylalanine (Phe). 
T a ble 7

Effect of irrigation treatments (TO, T1, and T2) on the concentrations of free amino acids $(\mathrm{g} / \mathrm{kg} D W)$ in the edible portion (peel and flesh) of jujube fruits

\begin{tabular}{|c|c|c|c|c|c|c|}
\hline \multirow{2}{*}{ Amino acids } & \multicolumn{6}{|c|}{ Treatment } \\
\hline & \multicolumn{2}{|l|}{ T0 } & \multicolumn{2}{|l|}{$\mathrm{T} 1$} & \multicolumn{2}{|l|}{$\mathrm{T} 2$} \\
\hline \multicolumn{7}{|l|}{ Essential } \\
\hline His & $0.6 \pm 8.2 \mathrm{E}-02$ & $\mathrm{a}$ & $0.4 \pm 4.8 \mathrm{E}-02$ & $\mathrm{a}$ & $0.9 \pm 0.2$ & $\mathrm{a}$ \\
\hline Thr & $0.6 \pm 1.4 \mathrm{E}-02$ & $\mathrm{a}$ & $0.5 \pm 4.0 \mathrm{E}-02$ & $\mathrm{a}$ & $0.2 \pm 3.4 \mathrm{E}-02$ & $\mathrm{~b}$ \\
\hline Lys & $0.1 \pm 2.1 \mathrm{E}-03$ & $\mathrm{a}$ & $0.1 \pm 3.4 \mathrm{E}-03$ & $\mathrm{a}$ & $6.0 \mathrm{E}-02 \pm 1.4 \mathrm{E}-03$ & $\mathrm{~b}$ \\
\hline Cys-cys & $8 \mathrm{E}-05 \pm 1 \mathrm{E}-05$ & $\mathrm{~b}$ & $1.2 \mathrm{E}-04 \pm 1.0 \mathrm{E}-05$ & $\mathrm{a}$ & $8.0 \mathrm{E}-05 \pm 1.0 \mathrm{E}-05$ & $\mathrm{~b}$ \\
\hline Tyr & $1.4 \pm 0.2$ & $\mathrm{a}$ & $0.7 \pm 5.3 \mathrm{E}-02$ & $\mathrm{~b}$ & $0.5 \pm 1.0 \mathrm{E}-02$ & $\mathrm{~b}$ \\
\hline Val & $0.3 \pm 5 \mathrm{E}-03$ & $\mathrm{a}$ & $0.2 \pm 1.3 \mathrm{E}-02$ & $\mathrm{a}$ & $0.1 \pm 9.5 \mathrm{E}-03$ & $\mathrm{~b}$ \\
\hline Met & $1.1 \mathrm{E}-03 \pm 1.0 \mathrm{E}-04$ & $\mathrm{a}$ & 8.7E-04 \pm 4 E-05 & $a b$ & $4.5 \mathrm{E}-04 \pm 3 \mathrm{E}-05$ & $\mathrm{~b}$ \\
\hline Leu + Ile & $0.1 \pm 4.6 \mathrm{E}-03$ & $\mathrm{a}$ & $9.7 \mathrm{E}-02 \pm 5.0 \mathrm{E}-03$ & $\mathrm{~b}$ & $4.7 \mathrm{E}-02 \pm 5.2 \mathrm{E}-03$ & $\mathrm{c}$ \\
\hline $\operatorname{Trp}$ & $0.2 \pm 3.2 \mathrm{E}-02$ & $\mathrm{~b}$ & $0.2 \pm 1.1 \mathrm{E}-02$ & $\mathrm{~b}$ & $0.4 \pm 5.0 \mathrm{E}-02$ & $\mathrm{a}$ \\
\hline Phe & $5.1 \mathrm{E}-02 \pm 7.6 \mathrm{E}-03$ & $\mathrm{a}$ & $2.4 \mathrm{E}-02 \pm 7.7 \mathrm{E}-04$ & $\mathrm{~b}$ & $1.8 \mathrm{E}-02 \pm 2.1 \mathrm{E}-03$ & $\mathrm{~b}$ \\
\hline \multicolumn{7}{|l|}{ Non-essential } \\
\hline Met-his & $6.0 \mathrm{E}-02 \pm 5.9 \mathrm{E}-03$ & $\mathrm{a}$ & $7.0 \mathrm{E}-02 \pm 2.0 \mathrm{E}-02$ & $\mathrm{a}$ & $5.0 \mathrm{E}-02 \pm 5.2 \mathrm{E}-03$ & $\mathrm{a}$ \\
\hline p-Нyp & $2.8 \pm 6.8 \mathrm{E}-02$ & $\mathrm{a}$ & $2.3 \pm 0.1$ & $\mathrm{a}$ & $1.5 \pm 0.2$ & $\mathrm{~b}$ \\
\hline Asn & $37.9 \pm 1.4$ & $\mathrm{a}$ & $33.6 \pm 3.3$ & $\mathrm{a}$ & $14.0 \pm 3.0$ & $\mathrm{~b}$ \\
\hline PEA & $1.2 \mathrm{E}-02 \pm 7.5 \mathrm{E}-04$ & $\mathrm{a}$ & $7.7 \mathrm{E}-03 \pm 8.8 \mathrm{E}-04$ & $\mathrm{~b}$ & $6.2 \mathrm{E}-03 \pm 4.0 \mathrm{E}-04$ & $\mathrm{~b}$ \\
\hline Arg & $4.0 \pm 0.3$ & $\mathrm{a}$ & $3.4 \pm 0.3$ & $\mathrm{a}$ & $1.4 \pm 0.2$ & $\mathrm{~b}$ \\
\hline Gln & $1.1 \pm 1.8 \mathrm{E}-02$ & $\mathrm{a}$ & $0.9 \pm 6.2 \mathrm{E}-02$ & $\mathrm{~b}$ & $0.3 \pm 2.9 \mathrm{E}-02$ & $\mathrm{c}$ \\
\hline Ser & $7.1 \pm 0.2$ & $\mathrm{a}$ & $6.3 \pm 0.6$ & $\mathrm{a}$ & $2.5 \pm 0.1$ & $\mathrm{~b}$ \\
\hline EA & $1.4 \pm 2.6 \mathrm{E}-02$ & $\mathrm{a}$ & $1.3 \pm 9.9 \mathrm{E}-03$ & $\mathrm{a}$ & $1.0 \pm 2.3 \mathrm{E}-02$ & $\mathrm{~b}$ \\
\hline Gly & $0.4 \pm 2.3 \mathrm{E}-02$ & $\mathrm{a}$ & $0.4 \pm 1.8 \mathrm{E}-02$ & $a b$ & $0.2 \pm 3.4 \mathrm{E}-02$ & $\mathrm{~b}$ \\
\hline Asp & $13.5 \pm 0.1$ & $\mathrm{a}$ & $9.7 \pm 0.7$ & $\mathrm{~b}$ & $2.1 \pm 6.8 \mathrm{E}-02$ & $\mathrm{c}$ \\
\hline Cit & $5.8 \mathrm{E}-02 \pm 1.5 \mathrm{E}-03$ & $\mathrm{a}$ & $3.8 \mathrm{E}-02 \pm 1.2 \mathrm{E}-04$ & $\mathrm{~b}$ & $2.0 \mathrm{E}-02 \pm 1.9 \mathrm{E}-03$ & $\mathrm{c}$ \\
\hline Glu & $6.3 \pm 0.4$ & $\mathrm{a}$ & $6.4 \pm 0.4$ & $\mathrm{a}$ & $1.3 \pm 0.3$ & $\mathrm{~b}$ \\
\hline Ala & $0.9 \pm 4.3 \mathrm{E}-02$ & $\mathrm{a}$ & $0.8 \pm 4.6 \mathrm{E}-02$ & $\mathrm{a}$ & $0.2 \pm 8.1 \mathrm{E}-02$ & $\mathrm{~b}$ \\
\hline GABA & $1.4 \pm 6.3 \mathrm{E}-02$ & $\mathrm{a}$ & $1.3 \pm 6.3 \mathrm{E}-02$ & $a b$ & $1.0 \pm 6.3 \mathrm{E}-02$ & $\mathrm{~b}$ \\
\hline AADA & $6.4 \mathrm{E}-02 \pm 3 \mathrm{E}-03$ & $\mathrm{a}$ & $3.8 \mathrm{E}-02 \pm 2.7 \mathrm{E}-03$ & $\mathrm{~b}$ & $4.7 \mathrm{E}-02 \pm 3.5 \mathrm{E}-03$ & $\mathrm{~b}$ \\
\hline Pro & $17.8 \pm 2.3$ & $\mathrm{~b}$ & $22.6 \pm 2.4$ & $a b$ & $26.9 \pm 2.0$ & $\mathrm{a}$ \\
\hline Orn & $0.3 \pm 1.0 \mathrm{E}-02$ & $\mathrm{a}$ & $7.8 \mathrm{E}-02 \pm 8.0 \mathrm{E}-4$ & $\mathrm{~b}$ & $6.2 \mathrm{E}-02 \pm 5.3 \mathrm{E}-04$ & $\mathrm{~b}$ \\
\hline BAIB & $8.3 \mathrm{E}-02 \pm 1.4 \mathrm{E}-03$ & $\mathrm{a}$ & $5.5 \mathrm{E}-02 \pm 2.6 \mathrm{E}-03$ & $\mathrm{~b}$ & $6.4 \mathrm{E}-02 \pm 5.6 \mathrm{E}-03$ & $a b$ \\
\hline AABA & $0.4 \pm 3.2 \mathrm{E}-03$ & $\mathrm{a}$ & $0.3 \pm 7 \mathrm{E}-04$ & $\mathrm{~b}$ & $0.2 \pm 3.4 \mathrm{E}-02$ & $\mathrm{~b}$ \\
\hline Cysta & $4.0 \mathrm{E}-03 \pm 2$ E-04 & $\mathrm{b}$ & $5.9 \mathrm{E}-03 \pm 4.1 \mathrm{E}-04$ & $\mathrm{a}$ & $5.4 \mathrm{E}-03 \pm 1.3 \mathrm{E}-03$ & $\mathrm{a}$ \\
\hline Hcys-cys & $1.9 \mathrm{E}-04 \pm 2 \mathrm{E}-05$ & $\mathrm{a}$ & $2.4 \mathrm{E}-04 \pm 2.0 \mathrm{E}-05$ & $\mathrm{a}$ & $1.6 \mathrm{E}-04 \pm 4.0 \mathrm{E}-05$ & $\mathrm{a}$ \\
\hline Total & $99.3 \pm 5.3$ & $\mathrm{a}$ & $92.0 \pm 7.5$ & $\mathrm{a}$ & $55.2 \pm 6.5$ & $\mathrm{~b}$ \\
\hline Total essential & $3.4 \pm 0.3$ & $\mathrm{a}$ & $2.2 \pm 0.1$ & $\mathrm{~b}$ & $2.2 \pm 0.4$ & $\mathrm{~b}$ \\
\hline
\end{tabular}

Means within a row followed by a different letter are significantly different according to Tukey's test $(P \leq 0.05)$.

Abbreviations as in Table 6.

Although the same amino acids were found in the fruit edible portion and pit, differences in the contribution of each free amino acid to the total free amino acids were evident (Tables 6-8). In the edible portion of $\mathrm{T} 0$ fruit, His, Thr, and Tyr constituted $77 \%$ of the total essential amino acid content. However, in pits, which had much lower amino acid content than the edible portion, His,
Thr, and Tyr constituted only $42 \%$ of the total essential amino acid content. Moreover, considering both essential and non-essential amino acids, Asn, Asp, Glu, and Pro constituted $76 \%$ of total amino acids in the T0 fruit edible portion but only $59 \%$ in pits (Tables 7 and 8).

Amino acids are the main transport forms of $\mathrm{N}$ in plants [51] and the irrigation treatments pro- 
duced similar changes in the total $\mathrm{N}$ and total free amino acid contents in the edible part of the fruit (Tables 5 and 7). This suggests that the decrease in total free amino acids in $\mathrm{T} 2$ fruits could have been due to a decrease in the transport of amino acids into fruits under this severe water deficit [52]. Alternatively, or as a complementary possibility, the decrease in total free amino acids in T2 fruits could have been caused by the partial inactivation of amino acid biosynthesis pathways in the fruit [52].

In addition to the fact that our results indicate high amounts of free amino acids in jujube fruits, it is important to emphasize the relatively high Asn content found in the edible portion of the

T a b l e 8

Effect of irrigation treatments $(T 0, T 1$, and T2) on the concentrations of free amino acids $(\mathrm{g} / \mathrm{kg} \mathrm{DW})$ in the pits (shell + seed) of jujube fruits

\begin{tabular}{|c|c|c|c|c|c|c|}
\hline \multirow[t]{2}{*}{ Amino acids } & \multicolumn{6}{|c|}{ Treatment } \\
\hline & \multicolumn{2}{|l|}{ T0 } & \multicolumn{2}{|l|}{$\mathrm{T} 1$} & \multicolumn{2}{|l|}{$\mathrm{T} 2$} \\
\hline \multicolumn{7}{|l|}{ Essential } \\
\hline His & $0.2 \pm 7.2 \mathrm{E}-02$ & $\mathrm{a}$ & $0.3 \pm 3.0 \mathrm{E}-02$ & $\mathrm{a}$ & $0.3 \pm 2.7 \mathrm{E}-02$ & $\mathrm{a}$ \\
\hline Thr & $0.2 \pm 6.5 \mathrm{E}-04$ & a & $0.2 \pm 9.1 \mathrm{E}-03$ & $\mathrm{a}$ & $0.1 \pm 5.6 \mathrm{E}-03$ & $\mathrm{~b}$ \\
\hline Lys & $6.4 \mathrm{E}-02 \pm 3.9 \mathrm{E}-03$ & $\mathrm{a}$ & $6.5 \mathrm{E}-02 \pm 3.1 \mathrm{E}-03$ & $\mathrm{a}$ & $5.4 \mathrm{E}-02 \pm 3.3 \mathrm{E}-04$ & $\mathrm{~b}$ \\
\hline Cys-cys & $1.7 \mathrm{E}-04 \pm 3.3 \mathrm{E}-06$ & $\mathrm{~b}$ & $2.0 \mathrm{E}-04 \pm 2.0 \mathrm{E}-06$ & $\mathrm{a}$ & $2.0 \mathrm{E}-04 \pm 3.6 \mathrm{E}-06$ & a \\
\hline Tyr & $0.1 \pm 7.2 \mathrm{E}-03$ & $\mathrm{a}$ & $0.1 \pm 1.2 \mathrm{E}-02$ & $\mathrm{a}$ & $0.1 \pm 1.4 \mathrm{E}-02$ & $\mathrm{a}$ \\
\hline Val & $6.3 \mathrm{E}-02 \pm 2.1 \mathrm{E}-03$ & a & $4.6 \mathrm{E}-02 \pm 6.3 \mathrm{E}-04$ & $\mathrm{~b}$ & $6.6 \mathrm{E}-02 \pm 3.3 \mathrm{E}-03$ & $\mathrm{a}$ \\
\hline Met & $3.4 \mathrm{E}-04 \pm 1.1 \mathrm{E}-05$ & $\mathrm{~b}$ & $6.6 \mathrm{E}-04 \pm 4.6 \mathrm{E}-05$ & $\mathrm{a}$ & $6.6 \mathrm{E}-04 \pm 8.4 \mathrm{E}-05$ & a \\
\hline Leu + Ile & $2.1 \mathrm{E}-02 \pm 7.5 \mathrm{E}-04$ & $\mathrm{a}$ & $2.1 \mathrm{E}-02 \pm 1.8 \mathrm{E}-04$ & $\mathrm{a}$ & $2.2 \mathrm{E}-02 \pm 8.6 \mathrm{E}-04$ & $\mathrm{a}$ \\
\hline Trp & $0.5 \pm 5.2 \mathrm{E}-02$ & $\mathrm{~b}$ & $0.4 \pm 1.9 \mathrm{E}-02$ & $\mathrm{~b}$ & $0.6 \pm 3.2 \mathrm{E}-02$ & $\mathrm{a}$ \\
\hline Phe & $6.7 \mathrm{E}-03 \pm 6.6 \mathrm{E}-05$ & $\mathrm{~b}$ & $6.5 \mathrm{E}-03 \pm 5.8 \mathrm{E}-05$ & $\mathrm{~b}$ & $8.2 \mathrm{E}-03 \pm 1.1 \mathrm{E}-03$ & $\mathrm{a}$ \\
\hline \multicolumn{7}{|l|}{ Non-essential } \\
\hline Met-his & $1.1 \mathrm{E}-02 \pm 4.8 \mathrm{E}-04$ & $a b$ & $9.0 \mathrm{E}-03 \pm 8.7 \mathrm{E}-04$ & $\mathrm{~b}$ & $1.2 \mathrm{E}-02 \pm 7.5 \mathrm{E}-04$ & a \\
\hline p-Нyp & $1.1 \pm 4.6 \mathrm{E}-02$ & $\mathrm{a}$ & $1.1 \pm 7.1 \mathrm{E}-02$ & $\mathrm{a}$ & $0.7 \pm 2.9 \mathrm{E}-02$ & $\mathrm{~b}$ \\
\hline Asn & $6.5 \pm 0.3$ & $\mathrm{a}$ & $6.4 \pm 0.9$ & $\mathrm{a}$ & $3.9 \pm 4.9 \mathrm{E}-02$ & $\mathrm{~b}$ \\
\hline PEA & $8.8 \mathrm{E}-04 \pm 2.9 \mathrm{E}-05$ & $\mathrm{~b}$ & $1.3 \mathrm{E}-03 \pm 1.2 \mathrm{E}-04$ & $\mathrm{a}$ & $1.8 \mathrm{E}-03 \pm 9.4 \mathrm{E}-05$ & $\mathrm{a}$ \\
\hline Arg & $4.6 \pm 4.1 \mathrm{E}-01$ & $\mathrm{~b}$ & $4.5 \pm 2.6 \mathrm{E}-01$ & $\mathrm{~b}$ & $5.6 \pm 0.3$ & $\mathrm{a}$ \\
\hline Gln & $0.3 \pm 4.2 \mathrm{E}-03$ & $\mathrm{a}$ & $0.2 \pm 1.1 \mathrm{E}-02$ & $\mathrm{~b}$ & $0.2 \pm 9.9 \mathrm{E}-04$ & $\mathrm{~b}$ \\
\hline Ser & $1.0 \pm 4.4 \mathrm{E}-02$ & a & $0.7 \pm 1.5 \mathrm{E}-02$ & $\mathrm{~b}$ & $0.5 \pm 1.3 \mathrm{E}-02$ & $\mathrm{c}$ \\
\hline EA & $0.1 \pm 6.0 \mathrm{E}-03$ & $\mathrm{~b}$ & $0.1 \pm 1.9 \mathrm{E}-03$ & $\mathrm{~b}$ & $0.2 \pm 1.9 \mathrm{E}-03$ & $\mathrm{a}$ \\
\hline Gly & $7.6 \mathrm{E}-02 \pm 2.6 \mathrm{E}-03$ & $\mathrm{a}$ & $8.1 \mathrm{E}-02 \pm 3.7 \mathrm{E}-03$ & $\mathrm{a}$ & $6.4 \mathrm{E}-02 \pm 4.2 \mathrm{E}-03$ & $\mathrm{~b}$ \\
\hline Asp & $1.7 \pm 8.3 \mathrm{E}-02$ & $\mathrm{a}$ & $1.5 \pm 1.5 \mathrm{E}-01$ & $\mathrm{a}$ & $1.6 \pm 5.5 \mathrm{E}-02$ & $\mathrm{a}$ \\
\hline Cit & $1.3 \mathrm{E}-02 \pm 1.3 \mathrm{E}-03$ & a & $1.2 \mathrm{E}-02 \pm 4.7 \mathrm{E}-04$ & $\mathrm{a}$ & $1.3 \mathrm{E}-02 \pm 1.4 \mathrm{E}-03$ & $\mathrm{a}$ \\
\hline Glu & $1.4 \pm 4.2 \mathrm{E}-02$ & a & $1.2 \pm 6.8 \mathrm{E}-02$ & $\mathrm{~b}$ & $1.0 \pm 0.2$ & $\mathrm{~b}$ \\
\hline Ala & $0.4 \pm 7.4 \mathrm{E}-03$ & $\mathrm{a}$ & $0.4 \pm 8.1 \mathrm{E}-03$ & $\mathrm{a}$ & $0.3 \pm 1.2 \mathrm{E}-02$ & $\mathrm{~b}$ \\
\hline GABA & $0.3 \pm 1.3 \mathrm{E}-02$ & $\mathrm{a}$ & $0.2 \pm 6.1 \mathrm{E}-03$ & $\mathrm{~b}$ & $0.2 \pm 9.9 \mathrm{E}-03$ & $\mathrm{~b}$ \\
\hline AADA & $1.2 \mathrm{E}-02 \pm 1.9 \mathrm{E}-03$ & $\mathrm{~b}$ & $1.4 \mathrm{E}-02 \pm 1.2 \mathrm{E}-03$ & $a b$ & $1.9 \mathrm{E}-02 \pm 4.2 \mathrm{E}-04$ & $\mathrm{a}$ \\
\hline Pro & $3.1 \pm 0.2$ & $\mathrm{~b}$ & $5.1 \pm 0.8$ & $\mathrm{a}$ & $6.7 \pm 0.7$ & $\mathrm{a}$ \\
\hline Orn & $3.6 \mathrm{E}-02 \pm 2.1 \mathrm{E}-03$ & $\mathrm{a}$ & $2.7 \mathrm{E}-02 \pm 1.4 \mathrm{E}-03$ & $\mathrm{~b}$ & $2.5 \mathrm{E}-02 \pm 7.6 \mathrm{E}-04$ & $\mathrm{~b}$ \\
\hline BAIB & $1.8 \mathrm{E}-03 \pm 1.2 \mathrm{E}-04$ & $\mathrm{ab}$ & $2.3 \mathrm{E}-03 \pm 1.7 \mathrm{E}-04$ & $\mathrm{a}$ & $1.5 \mathrm{E}-03 \pm 2.2 \mathrm{E}-05$ & $\mathrm{~b}$ \\
\hline AABA & $1.8 \mathrm{E}-03 \pm 9.7 \mathrm{E}-05$ & $\mathrm{~b}$ & $2.0 \mathrm{E}-03 \pm 2.2 \mathrm{E}-04$ & $a b$ & $1.0 \mathrm{E}-02 \pm 6.4 \mathrm{E}-03$ & $\mathrm{a}$ \\
\hline Cysta & $5.4 \mathrm{E}-04 \pm 3.5 \mathrm{E}-05$ & $\mathrm{~b}$ & $1.7 \mathrm{E}-03 \pm 2.2 \mathrm{E}-04$ & $\mathrm{a}$ & $2.0 \mathrm{E}-03 \pm 2.1 \mathrm{E}-04$ & $\mathrm{a}$ \\
\hline Hcys-cys & $3.2 \mathrm{E}-04 \pm 1.4 \mathrm{E}-05$ & a & $3.1 \mathrm{E}-04 \pm 7.8 \mathrm{E}-06$ & $\mathrm{a}$ & $1.8 \mathrm{E}-04 \pm 4.0 \mathrm{E}-06$ & $\mathrm{~b}$ \\
\hline Total & $21.6 \pm 1.3$ & $\mathrm{a}$ & $22.7 \pm 2.3$ & $\mathrm{a}$ & $22.3 \pm 1.5$ & $\mathrm{a}$ \\
\hline Total essential & $1.2 \pm 7.4 \mathrm{E}-02$ & $\mathrm{a}$ & $1.1 \pm 7.5 \mathrm{E}-02$ & $\mathrm{a}$ & $1.3 \pm 8.4 \mathrm{E}-02$ & $\mathrm{a}$ \\
\hline
\end{tabular}

Means within a row followed by a different letter are significantly different according to Tukey's test $(P \leq 0.05)$.

Abbreviations as in Table 6. 
fruit because Asn serves as a precursor of the potentially toxic acrylamide, which may be formed during the heat-processing of plant foods [15]. Recently, Choi et al. [4] showed that the Asn content of jujube fruit pulp decreased during the last stages of fruit growth, from 14.7 to $9.2 \mathrm{~g} / \mathrm{kg} \mathrm{DW}$; representing 54.9 and $31.9 \%$, respectively, of the total free amino acid content. In this sense, at harvest we found slightly higher Asn levels in the edible portion of the Grande de Albatera T0 fruits (37.9 $\mathrm{g} / \mathrm{kg}$ DW) (Table 7), which contributed $38.2 \%$ to the total free amino acid content. Despite the fact that most of the amino acids in both the edible portion and pits of jujube fruits showed a tendency to decrease as a result of water deficit, the decrease in the Asn content from 37.9 (T0) to $14.0 \mathrm{~g} / \mathrm{kg} \mathrm{DW}$ (T2) in the fruit edible portion and from 6.5 (T0) to $3.9 \mathrm{~g} / \mathrm{kg}$ DW (T2) in the pits must be considered advantageous. In other words, severe water deficit during fruit maturation can be considered as a helpful tool to decrease the fruit Asn content, hence reducing the risk of formation of the potentially toxic acrylamide.

A common response to water deficit is the accumulation in plant tissues of some amino acids, mainly Pro (Tables 7 and 8), which may be used to achieve osmotic adjustment [53]. In this study, Pro was the most abundant amino acid in both the edible portion and pit. Indeed, in the T0 fruit edible portion Pro contributed $18 \%$ to the total free amino acid content, whereas in $\mathrm{T} 1$ and $\mathrm{T} 2$ fruits this contribution was 25 and $49 \%$, respectively. Likewise, in the T0 pits Pro contributed $14 \%$ to the total free amino acid content, whereas in $\mathrm{T} 1$ and $\mathrm{T} 2$ fruits this contribution was 23 and $30 \%$, respectively (Tables 7 and 8). These increases suggest that Pro could contribute to osmotic adjustment in water stressed jujube fruits. The role of Pro may not be confined to osmotic adjustment, because it also helps the cell to overcome water stress-induced oxidative stress [52, 53]. Whatever the case, it is important to indicate that the response of Pro in jujube fruits to water deficit was not as sensitive as expected, because it is well known that Pro levels in leaves increase in response to drought in direct proportion to the magnitude of the water deficit $[54,55]$.

\section{CONCLUSIONS}

In contrast to previous findings, a major conclusion of our study is that, under our experimental conditions, jujube fruit maturation was sensitive to water deficit, because the yield and fruit size decreased and most of the chemical characteristics of the fruit were modified. To the best of our knowledge, this is the first time that one essential amino acid (Cys-cys) and seven non-essential amino acids (p-Hyp, AADA, Orn, BAIB, AABA, Cysta and HCys-Cys) have been identified in $Z$. jujuba fruits. The presence of four amino thiols (Cys-cys, Met, Cysta and Hcys-cys) underlines the functional character of these fruits.

Certain proportionality was observed in the response of jujube fruits to both deficit irrigation treatments. Fruits from plants exposed to moderate water deficit (T1) showed no change in fruit size, moisture content, firmness, or fruit peel and flesh color, but a decrease in fruit yield was accompanied by changes in ethylene emission, respiratory rate, and some fruit chemical characteristics, such as increases in the sucrose and arabinose contents, although no changes were found for most of the bioelements. This behavior indicates that $\mathrm{T} 1$ fruits entered the ripening phase earlier than control fruits and that moderate water deficit during fruit maturation improves jujube fruit eating quality because the fruits taste sweeter. Fruits from the more pronounced water deficit treatment (T2) showed decreased growth, resulting in smaller fruit size, lower moisture content and yield, and changes in firmness and peel and flesh color. Furthermore, changes in ethylene emission and the respiratory rate, likewise changes in chemical characteristics (increases of sugars and vitamin C and changes in organic acids), indicate that $\mathrm{T} 2$ fruits achieved a higher degree of ripening than $\mathrm{T} 0$ and $\mathrm{T} 1$ fruits, improving not only most of the fruit chemical characteristics that make up the taste but also the nutritional value.

The response of fruit amino acids to water deficit was not as sensitive as expected, since it did not show a direct relationship with the magnitude of the deficit. These results together with others, such as the decrease in fruit Asn content due to severe water deficit, may be the key to jujube fruit cultivation in arid and semiarid zones, due to a lower risk of acrylamide formation during fruit heat-processing.

Acknowledgements. The authors are grateful to the Projects AGL2010-19201-C04-01AGR and AGL 2011-23690 (CICYT), CSD 007-0063 (CONSOLIDER7 INGENIO 2010 "FUN-C-FOOD"), and CSIC 201170E041 (Spanish Ministry of Economy and Competitiveness), the Agencia Española de Cooperación Internacional para el Desarrollo (AECID) (A1/035430/11), the Fundación Séneca (04486/GERM/06), and the Ibero American Programme for Science, Technology and Development (CYTED), Action 112RT0460 CORNUCOPIA. ZNC, JCG, and AG were funded by a grant of the AECID, FPI and FPU Fellowship Programme, respectively, from the Spanish government. 


\section{REFERENCES}

[1] W. H. Outlaw, S. Q. Zhang, K. A. Riddle, A. K. Womble, L. C. Anderson, W. M. Outlaw, N. N. Outlaw, E.C. Outlaw, A.B. Thistle, The jujube (Zizyphus jujuba Mill.), a multipurpose plant. Econ. Bot., 56, 198-200 (2002).

[2] S. Azam-Ali, E. Bonkoungou, C. Bowe, C. Dekock, A. Godara, J. T. Williams, Fruits for the Future, 2: Ber and Other Jujubes, Revised ed., International Centre for Underutilised Crops: Southampton, U.K., p. 289, 2006.

[3] J. Collado-González, Z. N. Cruz, P. Rodríguez, A. Galindo, F. G. Díaz-Baños, J. García de la Torre, F. Ferreres, S. Medina, A. Torrecillas, A. Gil-Izquierdo, Effect of water deficit and domestic storage on the procyanidin content, size and aggregation process in pear-jujube (Z. jujuba) fruits. J. Agric. Food Chem., 61, 6187-6197 (2013).

[4] S. H. Choi, J. B. Ahn, H. J. Kim, N. K. Im, N. Kozukue, C. Levin, M. Friedman, Changes in free amino acid, protein, and flavonoid content in jujube (Ziziphus jujuba) fruit during eight stages of growth and antioxidative and cancer cell inhibitory effects by extracts. J. Agric. Food Chem., 60, 10245-10255(2012).

[5] Q. H. Gao, C. S. Wu, M Wang,. B. N. Xu, L. J. Du, Effect of drying of jujubes (Ziziphus jujuba Mill.) on the contents of sugars, organic acids, alpha-tocopherol, betacarotene, and phenolic compounds. J. Agric. Food Chem., 60, 9642-9648 (2012).

[6] S. H. Choi, J. B. Ahn, N. Kozukue, C. E. Levin, M. Friedman, Distribution of free amino acids, flavonoids, total phenolics, and antioxidative activities of jujube (Ziziphus jujuba) fruits and seeds harvested from plants Grown in Korea. J. Agric. Food Chem., 59, 6594-6604 (2011).

[7] J. W. Li, L. P. Fan, S. D. Ding, X. L. Ding, Nutritional composition of five cultivars of chinese jujube. Food Chem., 103, 454-460 (2007).

[8] X. Huang, A. Kojima-Yuasa, T. Norikura, D. Kennedy, T. Hasuma, I. Matsui-Yuasa, Mechanism of the anticancer activity of Zizyphus jujuba in HepG2 cells. Am. J. Chinese Med., 35, 517-532(2007).

[9] H. J. Heo, Y. J. Park, Y. M. Suh, S. J. Choi, M. J. Kim, H. Y. Cho, Y. J. Chang, B. Hong, H. K. Kim, E. Kim, C. J. Kim, B. G. Kim, D. H. Shin, Effects of oleamide on choline acetyltransferase and cognitive activities. Biosci. Biotech. Bioch., 67, 1284-1291 (2003).

[10] Z. Zhao, M. Liu, P. Tu, Characterization of water soluble polysaccharides from organs of Chinese Jujube (Ziziphus jujuba Mill. cv. Dongzao). Eur. Food. Res. Technol., 226, 985-989(2008).

[11] R. T. Mahajan, M. Z. Chopda, Phyto-pharmacology of Ziziphus jujuba Mill - A plant review. Pharmacogn. Rev., 3, 320-329 (2009).

[12] H. S. Kim, Effects of the Zizyphus jujuba seed extract on the lipid components in hyperlipidemic rats. J. Food Sci. Nutr., 7, 72-77(2002).

[13] S. Guo, J. A. Duan, Y. P. Tang, N. Y. Yang, D. W. Qian, S. L. Su, E. X. Shang, Characterization of triterpenic acids in fruits of Ziziphus species by HPLCELSD-MS. J. Agric. Food Chem.,58, 6285-6289 (2010).
[14] F. Mestdagh, B. De Meulenaer, T. Cucu, C. Van Peteghem, Role of water upon the formation of acrylamide in a potato model system. J. Agric. Food Chem., 54, 9092-9098 (2006).

[15] M. Friedman, C. E. Levin, Review of methods for the reduction of dietary content and toxicity of acrylamide. J. Agric. Food Chem., 56, 6113-6140 (2008).

[16] Z. N. Cruz, P. Rodriguez, A. Galindo, E. Torrecillas, S. Ondoño, C. D. Mellisho, A. Torrecillas, Leaf mechanisms for drought resistance in Zizyphus jujuba trees, Plant Sci., 197, 77-83 (2012).

[17] N. Cui, T. Du, S. Kang, F. Li, J. Zhang, M. Wang, Z. Li, Regulated deficit irrigation improved fruit quality and water use efficiency of pear-jujube trees, Agr. Water Manag., 95, 489-497(2008).

[18] R. G. Allen, L. S. Pereira, D. Raes, M. Smith, Crop evapotranspiration: guidelines for computing crop water requirements, in: Irrigation and Drainage, FAO, Italy, Rome, Paper 56, 1998.

[19] K. Shackel, A plant-based approach to deficit irrigation in trees and vines, HortScience, 46, 173-177 (2011).

[20] M. I. Egea, P. Sanchez-Bel, M. C. Martinez-Madrid, F.B. Flores, F. Romojaro, The effect of beta ionization on the antioxidant potential of 'Bulida' apricot and its relationship with quality. Postharvest Biol. Tec.,46, 6370 (2007).

[21] C. D. Mellisho, I. Egea, A. Galindo, P. Rodríguez, J. Rodríguez, W. Conejero, F. Romojaro, A. Torrecillas, Pomegranate (Punica granatum L.) fruit response to different deficit irrigation conditions. Agr. Water Manag., 114, 30-36 (2012).

[22] M. C. Martínez-Madrid, M. Serrano, F. Riquelme, F. Romojaro, Polyamines, abscisic acid and ethylene production in tomato fruit. Phytochemistry, 43, 323-326 (1996).

[23] I. Egea, F. B. Flores, M. C. Martínez-Madrid, F. Romojaro, P. Sánchez-Bel, 1-Methylcyclopropene affects the antioxidant system of apricots (Prunus armeniaca L. cv. Búlida) during storage at low temperature. J. Sci. Food Agric., 90, 549-555 (2010).

[24] P. Sánchez-Bel, I. Egea, F. Romojaro, M. C. MartínezMadrid, Sensorial and chemical quality of electron beam irradiated almonds (Prunus amygdalus). LWT - Food Sci. Technol., 41, 442-449 (2008).

[25] C. Salazar, J. M. Armenta, D. F. Cortés, V. Shulaev, Combination of an AccQ·Tag-ultra performance liquid chromatographic method with tandem mass spectrometry for the analysis of amino acids. Methods Mol. Biol., 828, 13-28 (2012).

[26] Y. Nagumo, K. Tanaka, K. Tewari, K. Thiraporn, T. Tsuchida, T. Honma, N. Ohtake, K. Sueyoshi, Y. Takahashi, T. Ohyama, Rapid quantification of cyanamide by ultra-high-pressure liquid chromatography in fertilizer, soil or plant samples. J. Chromatogr. A., 1216, 56145618 (2009).

[27] S. A. Cohen, Amino acid analysis using pre-column derivatization with 6-aminoquinolyl-N-hydroxysuccinimidyl carbamate: analysis of hydrolyzed proteins and electroblotted samples, in: Methods in Molecular Biology: Protein Sequencing Protocols, $2^{\text {nd }}$ ed., B. J. Smith 
(Ed), Humana Press Inc., Totowa, New Jersey, Vol. 211, pp 143-154, 2003.

[28] G. Fiechter, H. K. Mayer, UPLC analysis of free amino acids in wines: Profiling of on-lees aged wines. $J$. Chromatogr. B., 879, 1361-1366 (2011).

[29] B. A. Boughton, D. L. Callahan, C. Silva, J. Bowne, A. Nahid, T. Rupasinghe, D. L. Tull, M. J. McConville, A. Bacic, U. Roessner, Comprehensive profiling and quantitation of amine group containing metabolites. Anal. Chem.,83, 7523-7530 (2011).

[30] SPSS, Inc., SPSS Professional Statistics, Business Intelligence Division, Chicago, Vol. 12, 2002.

[31] D. C. Elfving, A. E. Hall, M. R. Kaufmann, Interpreting leaf water potential measurements with a model of soilplant-atmosphere continuum. Physiol. Plant., 27, 161168 (1972)

[32] A. Sellin, Base water potential of Picea abies as a characteristic of the soil water status., Plant Soil., 184, 273-280 (1996).

[33] Q. H. Gao, P. T. Wu, J. R. Liu, C. S. Wu, J. W. Parry, M. Wang, Physico-chemical properties and antioxidant capacity of different jujube (Ziziphus jujuba Mill.) cultivars grown in loess plateau of China. Sci. Hortic.Amsterdam, 130, 67-72 (2011).

[34] C.S. Wu, Q.H. Gao, X.D. Guo, J.G. Yu, M. Wang, Effect of ripening stage on physicochemical properties and antioxidant profiles of a promising table fruit 'pearjujube' (Zizyphus jujuba Mill.). Sci. Hortic.Amsterdam,148, 177-184 (2012).

[35] A. Salvador, J. Cuquerella, J. M. Martinez Javega, 1MCP treatment prolongs postharvest life of 'Santa Rosa' plums. J. Food Sci., 68, 1504-1510 (2003).

[36] A. A. Kader, Y. Li, A. Chordas, Post-harvest respiration, ethylene production, and compositional changes of chinese jujube fruits. HortScience, 17, 678-679 (1982).

[37] M. F. Abbas, R. A. M. Saggar, Respiration rate, ethylene production and certain chemical-changes during the ripening of jujube fruits. J. Hortic. Sci., 64, 223-225 (1989).

[38] M. F. Abbas, B. S. Fandi, Respiration rate, ethylene production and biochemical changes during fruit development and maturation of jujube (Ziziphus mauritiana Lamk). J. Sci. Food Agric., 82, 1472-1476 (2002).

[39] J. H. Al-Niami, R. A. M. Saggar, M. F. Abbas, The physiology of ripening of jujube fruit (Zizyphus spinachristi (L)Wild). Sci. Hortic.-Amsterdam, 51, 303-308 (1992).

[40] Z. Zhang, S. Tian, Z. Zhu, Y. Xu, G. Qin, Effects of 1methylcyclopropene(1-MCP) on ripening and resistance of jujube (Zizyphus jujuba cv. Huping) fruit against postharvest disease. LWT - Food Sci. Technol., 45, 1319 (2012).

[41] Q. Wang, T. Lai, G. Qin, S. Tian, Response of jujube fruits to exogenous oxalic acid treatment based on proteomic analysis. Plant Cell Physiol., 50, 230-242 (2009).
[42] Q. H. Gao, C. S. Wu, J. G. Yu, M. Wang, Y. J. Ma, C. L. Li, Textural characteristic, antioxidant activity, sugar, organic acid, and phenolic profiles of 10 promising jujube (Ziziphus jujuba Mill.) Selections. J. Food Sci., 77, C1218-C1225 (2012).

[43] Food and Nutrition Board, Commission on Life Sciences, National Research Council, in: Recommended Dietary Allowances, $10^{\text {th }}$ ed. National Academy Press, Washington, DC, United States, 1989.

[44] C. M. Ajila, U. J. S. Prasada Rao, Mango peel dietary fibre: Composition and associated bound phenolics. $J$. Funct. Foods,5, 444-450 (2013).

[45] A. Gribaa, F. Dardelle, A. Lehner, C. Rihouey, C. Burel, A. Ferchichi, A. Driouich, J. C. Mollet, Effect of water deficit on the cell wall of the date palm (Phoenix dactylifera 'Deglet nour', Arecales) fruit during development. Plant, Cell Environ., 36, 1056-1070 (2013).

[46] J. C. Favier, J. Ireland-Ripert,C. Laussucq, M. Feinberg, Table de composition des fruits exotiques, fruits de cueillette d'Afrique,in: Répertoire général des aliments, INRA et Lavoisier (Tec.Doc.) (Eds);Paris, Francia, 1993; Vol 3.

[47] A. Fadavi, M. Barzegar, M. H. Azizi, M. Bayat, Note. Physicochemical composition of ten pomegranate cultivars (Punica granatum L.) grown in Iran. Food Sci. Technol. Int., 11, 113-119 (2005).

[48] M. M. Hussein, Y. E. D. Camilia, Mineral constituents of Fenugreek varieties grown under water stress condition. Aust. J. Basic Appl. Sci., 5, 2904-2909 (2011).

[49] O. Demirkol, C. Adams, N. Ercal, Biologically important thiols in various vegetables and fruits. J. Agric. Food Chem., 52, 8151-8154 (2004).

[50] L. Zagorchev, C. Seal, I. Kranner, M. Odjakova, A Central role for thiols in plant tolerance to abiotic stress. Int. J. Mol. Sci., 14, 7405-7432 (2013).

[51] P. J. Lea, R. J. Ireland, Nitrogen metabolism in higher plants, in: Plant Amino Acids: Biochemistry and Biotechnology, B.Singh (Ed), Marcel Dekker Inc.,New York, pp. 1-47, 1999.

[52] K. Zushi, N. Matsuzoe, Free amino acid contents of tomato fruit grown under water and salinity stresses. Acta Hortic., 724, 91-96 (2006).

[53] D. P. Verma, Osmotic stress tolerance in plants: Role of proline and sulfur metabolism, in: Molecular responses to cold, drought, heat and salt stress in higher plants, $\mathrm{K}$. Shinozaki and K. Yagamuchi-Shinozaki (Eds), R. G. Landes Company, Texas, p 153-168, 1999.

[54] A. Torrecillas, A. León, F. Del Amor, M. C. RuizSánchez, Determination of free proline levels in citrus leaf-disks and its relation to xylem potential. Agrochimica, 28, 371-378 (1984).

[55] Q. Ma, D.W. Turner, D. Levy, W. A. Cowling, Solute accumulation and osmotic adjustment in leaves of Brassica oilseeds in response to soil water deficit. Aust. J. Agric. Res.,55, 939-945 (2004). 